\title{
The Abiotic and Biotic Factors and Their Relationships with The Population Density of The Sunt Wax Scale Insect, Waxiella Mimosae (Signoret) Infesting Sunt Trees in Luxor Governorate, Egypt
}

\author{
Moustafa Mohamed Sabry Bakry* \\ Scale Insects and Mealybugs Research Department, Plant Protection Research Institute, Egypt
}

Submission: September 03, 2018, Published: October 05, 2018

"Corresponding author: Moustafa Mohamed Sabry Bakry, Scale Insects and Mealybugs Research Department, Plant Protection Research Institute, A.R.C, Dokii, Giza, Egypt, Email: md.md_sabry@yahoo.com

\begin{abstract}
The main objective of the present work is to study the effect of the abiotic (Climatic weather) and biotic factors (Ants density) on the population density of Waxiella mimosae (Signoret) (Hemiptera: Coccidae) throughout two successive years (2016/2017 and 2017/2018) at Esna district, Luxor Governorate, Egypt. The obtained results showed that, the insect population of W. mimosae affected significantly with the tested weather factors viz., (daily mean maximum air temperature, daily mean minimum air temperature, mean of relative humidity and mean of dew point) during the two successive years and these factors varied from year to another. The percentages of explained variance (E.V.\%) indicate that all tested variables were responsible on variability in the total insect population by 45.65 and $51.56 \%$ during the first and second years, respectively. Also, the mean of relative humidity and dew point during the first year (2016/2017) was the most effective variables for the changes in the total insect population by 42.86 and $24.61 \%$, respectively and through the second year $(2017 / 2018)$, the daily mean minimum air temperature and mean of relative humidity was the most effective variables for the changes in the total population size by 36.99 and $30.33 \%$, respectively.
\end{abstract}

The obtained results revealed that, the mean numbers of total population of pest per branch through the whole year was $110.18 \pm 9.39$ and $114.06 \pm 9.71$ individuals per branch in trees containing ants during the first and second years, respectively and was $66.84 \pm 5.53$ and $65.21 \pm 5.41$ individuals per branch in trees which ants were excluded during the both years, respectively. Also, the synchronization between the percentages of (adult females and gravid females of pest) and percentages of (ants density) were good and the simple regression analysis were more correlated and its positive in all seasons of the year and on the over year during the two years of study. In contrary, the percentages of pre-adults individuals and the percentages of ants' density were not good and it exhibited negative response in all seasons of the year and on the whole year during the both two years. Generally, it may be concluded that the foraging ants can markedly stimulate the development of $W$. mimosae on sunt trees.

Keywords: Waxiella mimosa; Seasonal activity; Environmental conditions; Peaks; Ants and sunt trees

\section{Introduction}

The sunt wax scale insect, Waxiella mimosae (Signoret) = Ceroplastes mimosae (Signoret) (Hemiptera: Coccidae) is considered as one of the serious destructive pests infesting sunt trees. It causes severe damage to infested branches and the twigs sucking the plant sap with the mouth parts, causing thereafter deformations, drying up of young twigs and death of twigs by the action of the toxic saliva and excreting large amount of honeydew that encourages the growth of sooty mould with blackens the branches, decreases photosynthesis activity, and decreased vegetative growth of the infested trees [1,2]. A characteristic symptom of infestation by pest is the appearance and accumulation of its scales on attacked sunt parts and the waxy covering of adjacent individuals becomes confluent, rendering it difficult to ascertain the real form [3].

To develop an effective control against $W$. mimosae, it is essential to know its bio-ecology including population dynamics and climatic factors influencing the life history and the densities of different phenological stages. Weather factors play a great role on the population abundance of many insect species. Temperature and relative humidity has a direct influence on insect activity, 
rate of development and may have on the insects' physiology and behavior [4].

Honeydew excretions by hemipterans are the result of feeding on the plant sap [5]. Ants attendance of homopterous, especially coccids are a well phenomenon [6]. Most of honeydew-seeking ants visit several species of hemipteran and are more specific in their attendance $[7,8]$. In addition to causing sooty mold growth on the host plant, which may inhibit photosynthesis [9], honeydew of hemipterans is known to attract many ant species [10]. The presence of attendant ants may be beneficiary to coccids in one or more way:

a. If ants are excluded, coccids may become engulfed in their own honeydew and die [11].

b. Certain ant species are know to transport coccids to new feeding sites on the same plants or to uninfested plants, thus greatly facilitating the spread of hemipteran population [12].

c. Ants frequently build protective covers or nest over coccid aggregation on plants [13]. These shelters may benefit the coccids by providing protection from weather [14]. Also, coccids may be less susceptible to fungal attack within rather than outside ant nests due to the antibiotic action of the secretion produced by most ants.

d. Ants may be lead to changes to ecosystem composition and dynamics [15]. In both agricultural and horticultural systems, the majority of ant exclusion studies have reported a significant positive interaction between ants and coccids [16], and a significant negative interaction between ants and natural enemies [16]. The total number of coccids increased dramatically in the presence of ants [17]. Carroll \& Janzen [18], suggested that the more dependant an ant colony appears to be on homopterous, the more likely that the ants are harvesting them for protein and lipids as well as honeydew. Lipids and proteins play a vital part in ant nutrition [19], but the importance of coccids as food items for ant is small in comparison with the use of their honeydew as a carbohydrate for energy source [6].

Rare informations in the literature concerning the impact of the abiotic and biotic factors on the population density of this pest. So, it is necessary to do this study where there is no reported similar research. Therefore, the present work was carried out to study the effect of the abiotic factors (climatic weather) and biotic factors (symbiosis or mutualism by ants) on the population density of W. mimosae under the field condition in Luxor Governorate.

\section{Materials and Methods}

\section{Effect of the abiotic factor (Climatic weather) on the activity of different stages of $W$. mimosae population}

The population fluctuations of this scale found infesting sunt trees, Acasia arabica (Family: Fabaceae) were carried out at half-monthly intervals at Esna district, Luxor Governorate. This experiment was extended the two successive years for studying the population fluctuations of this insect from September $10^{\text {th }}$,
2016 until August $25^{\text {th }}, 2018$. Four sunt trees were grown on the edges of water canales were heavily infested with the sunt wax scale insect, $W$. mimosae (Signoret) and were chosen for this study. The selected trees were almost similar and as uniform as possible in size, age, shape, height, vegetative growth. Regular half-monthly samples were picked up to random from different directions and stratums of tree with rate of 15 branches $(20 \mathrm{~cm}$. long) per tree. The samples were collected regularly and immediately transferred to laboratory in polyethylene bags for inspection using a stereomicroscope. Numbers of alive insects of trees were individually sorted into immature stages (pre-adults population) and mature stages (adult females and gravid females) and then were counted and recorded together opposite to each inspected date. The wax scale insect was collected and identified by Dr. Fatma Abd ElHalim Moharum, Department of scale insect and Mealybugs, Plant Protection Research Institute, Agric. Res. Center, Egypt. The meteorological data of the half monthly means of the some climatic factors viz., daily mean maximum temperature, minimum temperature, mean of $\%$ relative humidity and mean of dew point ${ }^{\circ} \mathrm{C}$ for conditions of Luxor Governorate was obtained from the Central Laboratory for Agricultural Climate, Agriculture Research Center, Ministry of Agriculture in Giza. The altitude, latitude and longitude of this weather region of Luxor were $99 \mathrm{~m}, 25.67^{\circ} \mathrm{N}$ and $32.71^{\circ} \mathrm{E}$, respectively. Population of pest and weather data were tabulated and graphically plotted against each other. The population of W. mimosae is influenced, in general, by many factors including the behavior of insect and weather factors. According to the results of the simple correlation, simple regression coefficient and the partial regression formula which was adopted to find out the simultaneous effects of tested main weather factors on the population density of different stages of $W$. mimosae. The partial regression method termed the C-multipliers was adopted according to Fisher [20]. This method was helpful in obtaining basic information about the amount of variability in the insect populations that could be attributed to these factors, together, which was calculated as percentage of explained variance (E.V.\%) and it determines the single effect of each factor on the population changes. The partial regression values indicate the average rate of change in insect activity due to a unit change in any of the tested factors under test.

\section{Effect of the biotic factor (ants density) on the activity of different stages of $W$. mimosae population}

Impact of ants exclusion versus ants presence on the population density of different stages of $W$. mimosae on sunt trees: Concerning, the effect of ants exclusion versus ants presence on population size of different stages of $W$. mimosae were carried out at Esna district, Luxor Governorate during the two successive years extending from September 10th, 2016 until August $25^{\text {th }}, 2018$.

a. Eight sunt trees were separated as follows: Four sunt trees without application any chemical control measures before and during the period of study (data of the population density of pest above mentioned is considered an indicator to the presence 
of ants). The four trees other were treated with pesticide diazinon $60 \% \mathrm{EC}$ at the rate $(3 \mathrm{ml} / 1$ liter water) during September $1 \mathrm{st}$, in every year for excluding ant individuals. The treated trees were completely sprayed by the pesticide (diazinon) using six horse power motor sprayer (beam), with a 600 liters tank at pressure of two pounds per square inch. Each tree received 20-25 liters of the solution to ensure complete covering of all tree parts. The foraging ants associated were identified by the specialists in the classification Research Department, Plant Protection Research Institute, Agric. Res. Center, Egypt.

Regular half-monthly samples were picked up to random from different directions and stratums of tree with rate of 15 branches $(20 \mathrm{~cm}$. long) per tree for the trees treated and untreated were collected, sorted, counted and recorded as above mentioned. In order to compare the population density of pest in ants exclusion and presence of ants on branches of sunt trees on the basis of average number of individuals per branch at the successive sampling dates under the same climatic conditions. Also, the paired T-test was used to establish whether a significant difference exists between the population density of pest in ants exclusion or presence of ants on branches of sunt trees at $\mathrm{P} \leq 0.05$.

Estimate of the relationship between the percentages of the different stages of $W$. mimosae population and the percentage of ants density, Messon sp. on branches of sunt trees during the period of this investigation:

a. The percentages of the different stages (age structure) of $\boldsymbol{W}$. mimosae calculation: To calculate the age structure per sample, the mean number of each stage was divided by the total and multiplied by 100 . This way gave each stage a percent proportion of the total per sample regardless of the total number of presented insect (i.e. population density).

The percentage of ants' population was calculated according to the following equation:

$$
\% A \text { nts population }=\frac{\text { No. ants population. }}{\text { No. ants population }+ \text { total inscent population of W. mimosae. }} x 100
$$

Averages of population densities of insect, the percentage of ants and weather conditions was calculated by Excel sheets and shown graphically. The data obtained were statistically analyzed by using simple correlation which the independent variable $(\mathrm{x})$ representing the percentages of different stages of $W$. mimosae population and the dependent variable (y) represented the percentage of ants density. A linear regression model was performed to analyze the relationship between both of them was adopted according to Fisher [20].

The equation of linear regression was calculated according to the following formula:

$$
Y=a \pm b x
$$

Where;

$\mathrm{Y}=$ Prediction value (Dependent variable) $\mathrm{x}=$ Independent variable

$\mathrm{a}=$ Constant $(\mathrm{y}$ - intercept $) \mathrm{b}=$ Regression coefficient

Statistical analysis in the present work was carried out with Computer using [21], to determine the preferable time for the insect activity and the proper time for its control.

\section{Results and Discussion}

\section{Effect of the abiotic factors (main climatic weather) on the activity of different stages of W. mimosae population}

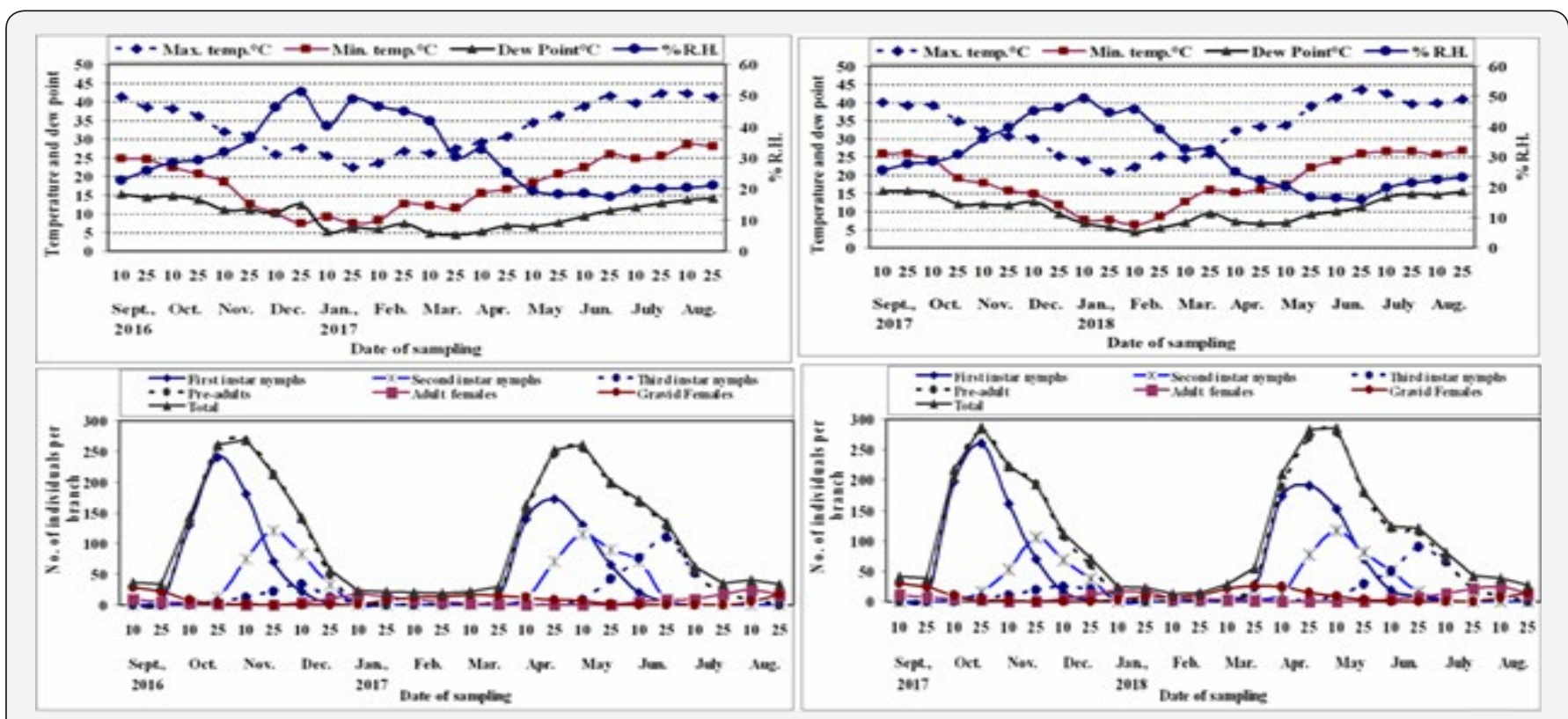

Figure 1: Means of half monthly counts of different stages and the population density of $W$. mimosae on sunt trees, with climatic factors affecting at Esna district, Luxor Governorate during the two year of (2016/2017 and 2017/2018). 

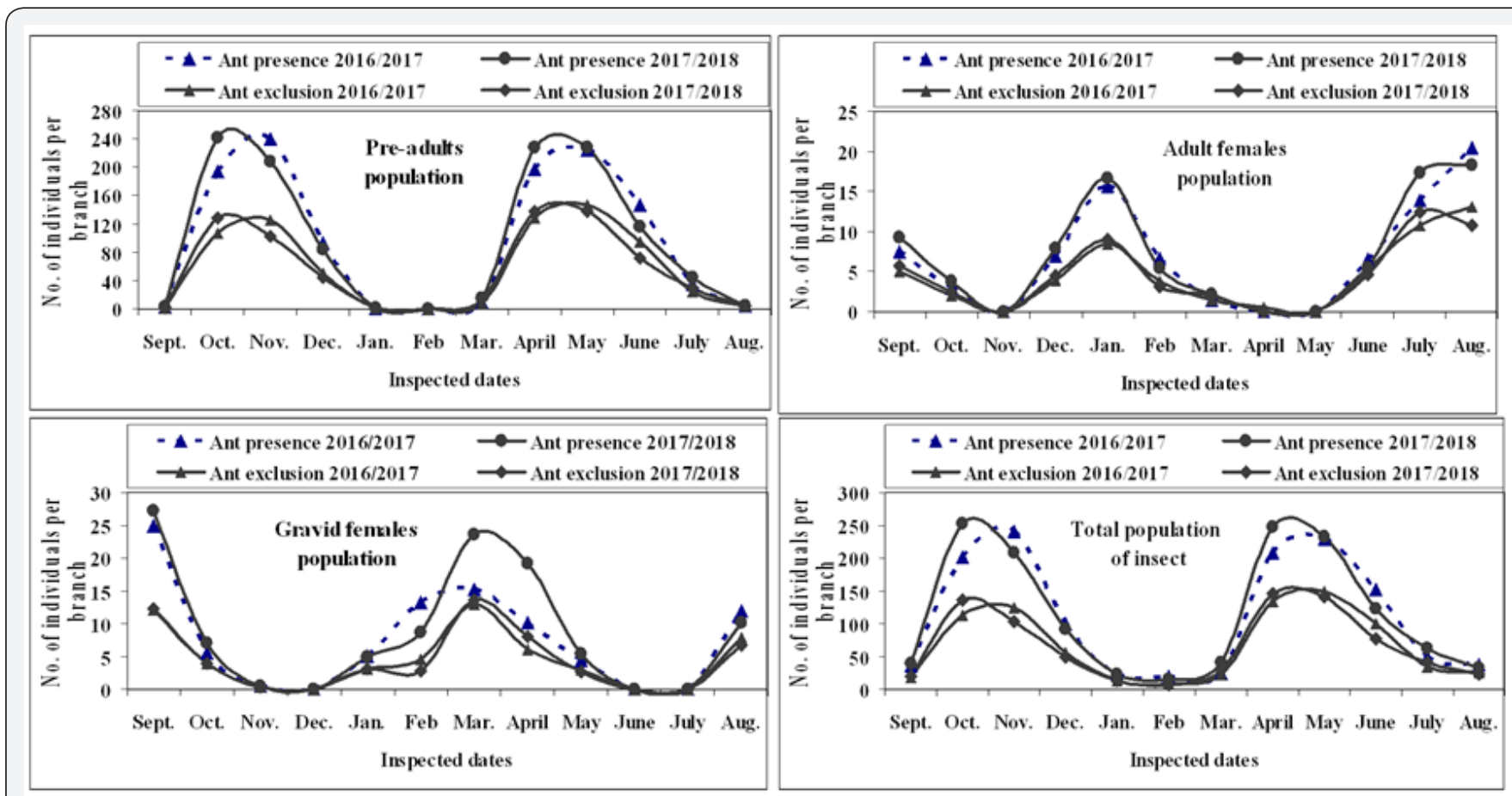

Figure 2: Impact of ants exclusion versus ants presence on the population density of different stages of W. mimosae on sunt trees at Esna district, Luxor Governorate during the two successive years of (2016 to 2018).

The half-monthly counts of $W$. mimosae different stages infested sunt trees at Esna district, Luxor Governorate were recorded through the two successive years (2016/2017 and $2017 / 2018)$. Also, means of the half-monthly records of temperature, relative humidity and dew point throughout the two years of investigations and are represented in Figure $1 \& 2$. To discuss the relationships between the main weather factors and the seasonal activity of different stages of $W$. mimosae on the basis of average number of immature and mature stages counts per branch at the successive sampling dates.

\section{The pre-adults population (immature stages)}

Effect of daily mean maximum temperature: The results of statistical analysis of simple correlation in Table 1 showed slight positive insignificant correlation between the daily mean maximum temperature and pre-adults population of $W$. mimosae, $r$ values were $(+0.08$ and +0.21$)$ during the two years of study, respectively. The unit effect regression coefficient (b) indicates that an increase of $1^{\circ} \mathrm{C}$ in the daily mean maximum temperature, would increase the population by 1.27 and 3.02 individuals per branch in the two years, respectively, Table 1. Concerning, the partial regression values are represented in Table 2, emphasized an significant negative relation $(-40.50)$, the partial correlation was $(-0.45)$ and (t-test) value was $(-2.20)$ in the first year $(2016 / 2017)$ and a significant positive (P. reg. value was +29.00 ), the partial correlation was $(+0.54)$ and the t-test value was $(+2.83)$ during the second year (2017/2018), when the mean daily minimum temperature, relative humidity and dew point become around their means. The obtained results revealed that, daily mean maximum temperature above the optimum range of the pre-adults activity in the first year (2016/2017) and under the optimum range of the pre-adults pop- ulation during the second year $(2017 / 2018)$ and this factor was responsible for the certain changes in the pre-adults population by 14.17 and $21.31 \%$ during the first and second years, respectively.

Effect of daily mean minimum temperature: Data in Table 1 showed the correlation coefficient (r) between daily mean minimum temperature and the pre-adults population for the $1^{\text {st }}$ and $2^{\text {nd }}$ years were insignificant positive and feeble $(+0.07$ and +0.09$)$, respectively. The calculated regression coefficient (b) for the effect of this factor indicated that for every $1{ }^{\circ} \mathrm{C}$ increase, the population would increase by 1.00 and 1.36 individuals per branch for two years of study, respectively, Table 1 . The real effect of this factor on pre-adults population revealed that, it was insignificant negative from the partial regression (P. reg. value $=-10.38$ ), the partial correlation was $(-0.21)$ and t-test value was $(-0.92)$ in the first year $(2017 / 2018)$ and highly significant negative effect $(\mathrm{P}$. reg. value $=$ -111.16) the partial correlation was (-0.64) and t value was (-3.59) in the second year, when the mean daily maximum temperature, relative humidity and dew point become around their means (Table 2). The obtained results revealed that, mean minimum temperature was around the optimum range of pre-adults activity in the first year and entirely above the optimum range in the second year. This climatic factor was the least effective variable in changes of the pre-adults population by $2.48 \%$ during the first year and was the most effective variable for the changes in the pre-adults activity during the second year by $34.39 \%$ (Table 2 ).

Effect of the mean relative humidity: Data obtained are represented in Table 1, showed that the mean relative humidity had insignificant negative effect on pre-adults activity, since the correlation coefficient ( $\mathrm{r}$ values were -0.27 and -0.28 ) for the $1^{\text {st }}$ and 
$2^{\text {nd }}$ years, respectively. The unit effect (regression coefficient) indicates that an increase of $1 \%$ in the mean relative humidity, would decrease the population density by 2.44 and 2.74 individuals per branch for the two years, respectively, Table 1 . The exact effect of this climatic factor appeared from the partial regression values in (Table 2), which showed that it was highly significant negative effect (P. reg. values were -24.77 and -31.61 ) and the values of the partial correlation were $(-0.65$ and -0.58$)$ and $t$ values were $(-3.76$ and -3.13) when the mean daily maximum temperature, minimum temperature and dew point become around their means, Table 2. The obtained results revealed that, mean relative humidity was entirely above the optimum range of pre-adults activity during the two years and this climatic factor was the most effective variable for the changes in the pre-adults population by $41.51 \%$ for the first year and was responsible for the certain changes in population for the second year by $26.20 \%$ (Table 2).

Table 1: Simple correlation and regression values when the counts of the climatic factors were plotted versus the population density of different stages of $W$. mimosae during the two successive years of (2016 to 2018).

\begin{tabular}{|c|c|c|c|c|c|c|c|c|}
\hline \multirow{2}{*}{ Years } & \multirow{2}{*}{ Stages } & \multirow{2}{*}{ Tested Factors } & \multicolumn{6}{|c|}{ Simple Correlation and Regression Values } \\
\hline & & & $\mathbf{a}$ & $\mathbf{r}$ & b & S. E & $\mathbf{t}$ & C.V. \\
\hline \multirow{16}{*}{ First Year $(2016 / 2017)$} & \multirow{4}{*}{ Pre-adults } & Max. temp. & 53.63 & 0.08 & 1.27 & 3.22 & 0.39 & 1.07 \\
\hline & & Min. temp. & 77.88 & 0.07 & 1 & 3.08 & 0.32 & 1.07 \\
\hline & & R.H.\% & 170.56 & -0.27 & -2.44 & 1.86 & -1.31 & 1.04 \\
\hline & & Dew point & 99.9 & -0.02 & -0.43 & 5.86 & -0.07 & 1.08 \\
\hline & \multirow{4}{*}{ Adult Females } & Max. temp. & -2.83 & 0.28 & 0.29 & 0.22 & 1.36 & 1 \\
\hline & & Min. temp. & 2.19 & 0.26 & 0.26 & 0.21 & 1.28 & 1 \\
\hline & & R.H.\% & 7.92 & -0.05 & -0.03 & 0.13 & -0.25 & 1.04 \\
\hline & & Dew point & 0.86 & 0.32 & 0.61 & 0.38 & 1.59 & 0.98 \\
\hline & \multirow{4}{*}{ Gravid Females } & Max. temp. & 7.07 & 0.01 & 0.02 & 0.26 & 0.06 & 1.08 \\
\hline & & Min. temp. & 5.5 & 0.1 & 0.12 & 0.24 & 0.48 & 1.07 \\
\hline & & R.H.\% & 7.35 & 0.01 & 0.01 & 0.15 & 0.05 & 1.08 \\
\hline & & Dew point & 6.99 & 0.03 & 0.06 & 0.47 & 0.13 & 1.08 \\
\hline & \multirow{4}{*}{ Total } & Max. temp. & 57.86 & 0.11 & 1.57 & 2.95 & 0.53 & 0.85 \\
\hline & & Min. temp. & 85.56 & 0.1 & 1.38 & 2.82 & 0.49 & 0.85 \\
\hline & & R.H.\% & 185.83 & -0.3 & -2.47 & 1.69 & -1.46 & 0.82 \\
\hline & & Dew point & 107.75 & 0.01 & 0.25 & 5.38 & 0.05 & 0.86 \\
\hline \multirow{16}{*}{ Second Year (2017/2018) } & \multirow{4}{*}{ Pre-adults } & Max. temp. & -2.44 & 0.21 & 3.02 & 2.98 & 0.02 & 1.04 \\
\hline & & Min. temp. & 73.07 & 0.09 & 1.36 & 3.14 & 1.19 & 1.06 \\
\hline & & R.H.\% & 180.86 & -0.28 & -2.74 & 1.97 & -2.87 & 1.02 \\
\hline & & Dew point & 113.14 & -0.05 & -1.44 & 5.93 & -1.71 & 1.07 \\
\hline & \multirow{4}{*}{ Adult Females } & Max. temp. & 2.95 & 0.13 & 0.13 & 0.21 & 0.41 & 1.01 \\
\hline & & Min. temp. & 3.34 & 0.2 & 0.21 & 0.22 & 0.79 & 1 \\
\hline & & R.H.\% & 5.85 & 0.07 & 0.04 & 0.14 & 1.27 & 1.02 \\
\hline & & Dew point & 0.38 & 0.33 & 0.65 & 0.39 & 0.09 & 0.96 \\
\hline & \multirow{4}{*}{ Gravid Females } & Max. temp. & 11.98 & -0.07 & -0.09 & 0.29 & -1.22 & 1.11 \\
\hline & & Min. temp. & 8 & 0.03 & 0.05 & 0.3 & 1.37 & 1.12 \\
\hline & & R.H.\% & 11.94 & -0.11 & -0.1 & 0.19 & -1.93 & 1.11 \\
\hline & & Dew point & 8.65 & 0.01 & 0.02 & 0.56 & 1.38 & 1.12 \\
\hline & \multirow{4}{*}{ Total } & Max. temp. & 12.49 & 0.23 & 3.05 & 2.77 & 0.13 & 0.83 \\
\hline & & Min. temp. & 84.42 & 0.12 & 1.62 & 2.93 & 1.47 & 0.85 \\
\hline & & R.H.\% & 198.65 & -0.31 & -2.79 & 1.82 & -3.4 & 0.82 \\
\hline & & Dew point & 122.17 & -0.03 & -0.77 & 5.55 & -1.98 & 0.86 \\
\hline
\end{tabular}

$\mathrm{a}=$ Constant; $\mathrm{S} . \mathrm{E}=$ Standard error; $\mathrm{P}=$ Probability; $\mathrm{C} . \mathrm{V} .=$ Coefficient of variation is a relative measure of dispersion, computed by dividing root mean square error by the mean of the dependent variable. But, it can be useful in comparative studies.

$C V=\frac{\sqrt{M S E}}{y}$ 


\section{Agricultural Research \& Technology: Open Access Journal}

Table 2: Multiple regression and correlation analyses between three climatic factors and the population density of different stages of $W$. mimosae during the two successive years of (2016 to 2018).

\begin{tabular}{|c|c|c|c|c|c|c|c|c|c|c|c|c|c|c|}
\hline \multirow[b]{2}{*}{ Years } & \multirow[b]{2}{*}{ Stages } & \multirow[b]{2}{*}{$\begin{array}{l}\text { Tested } \\
\text { Factors }\end{array}$} & \multicolumn{4}{|c|}{ Partial Regression Values } & \multirow{2}{*}{$\begin{array}{l}\text { Partial } \\
\text { Cor- } \\
\text { rela- } \\
\text { tion }\end{array}$} & \multirow{2}{*}{$\begin{array}{c}\text { Effi- } \\
\text { ciency } \\
\%\end{array}$} & \multirow[b]{2}{*}{ Rank } & \multicolumn{5}{|c|}{ Analysis Variance } \\
\hline & & & Constant & P. reg. & S. E & $\mathbf{t}$ & & & & $\begin{array}{l}\text { F val- } \\
\text { ues }\end{array}$ & C.V. & MR & $\mathbf{R}^{2}$ & E.V.\% \\
\hline \multirow{16}{*}{$\begin{array}{c}\text { First Year } \\
(2016 / 2017)\end{array}$} & \multirow{4}{*}{$\begin{array}{l}\text { Pre- } \\
\text { adults }\end{array}$} & Max. temp. & \multirow{4}{*}{$2005.90^{* *}$} & -40.5 & 18.43 & $-2.20^{*}$ & -0.45 & 14.17 & 3 & \multirow{4}{*}{$3.77^{*}$} & \multirow{4}{*}{0.87} & \multirow{4}{*}{0.67} & \multirow{4}{*}{0.44} & \multirow{4}{*}{44.25} \\
\hline & & Min. temp. & & -10.38 & 11.28 & -0.92 & -0.21 & 2.48 & 4 & & & & & \\
\hline & & R.H.\% & & -24.77 & 6.58 & $-3.76^{* *}$ & -0.65 & 41.51 & 1 & & & & & \\
\hline & & Dew Point & & 38.86 & 13.85 & $2.81^{*}$ & 0.54 & 23.1 & 2 & & & & & \\
\hline & \multirow{4}{*}{$\begin{array}{l}\text { Adult } \\
\text { fe- } \\
\text { males }\end{array}$} & Max. temp. & \multirow{4}{*}{$-114.47^{*}$} & 2.8 & 1.36 & 2.07 & 0.43 & 14.13 & 2 & \multirow{4}{*}{2.81} & \multirow{4}{*}{0.88} & \multirow{4}{*}{0.61} & \multirow{4}{*}{0.37} & \multirow{4}{*}{37.2} \\
\hline & & Min. temp. & & 0.31 & 0.83 & 0.37 & 0.08 & 0.45 & 4 & & & & & \\
\hline & & R.H.\% & & 1.37 & 0.48 & $2.83^{*}$ & 0.54 & 26.46 & 1 & & & & & \\
\hline & & Dew Point & & -1.97 & 1.02 & -1.93 & -0.4 & 12.31 & 3 & & & & & \\
\hline & \multirow{4}{*}{$\begin{array}{l}\text { Gravid } \\
\text { Fe- } \\
\text { males }\end{array}$} & Max. temp. & \multirow{4}{*}{18.8} & -1.77 & 1.78 & -1 & -0.22 & 4.28 & 2 & & & & & \\
\hline & & Min. temp. & & 2.2 & 1.09 & 2.02 & 0.42 & 17.66 & 1 & & & & & \\
\hline & & R.H.\% & & 0.29 & 0.63 & 0.46 & 0.11 & 0.92 & 3 & 1.04 & 1.05 & 0.42 & 0.18 & 18 \\
\hline & & Dew Point & & -0.07 & 1.33 & -0.05 & -0.01 & 0.01 & 4 & & & & & \\
\hline & & Max. temp. & & -39.47 & 16.7 & $-2.36^{*}$ & -0.48 & 15.97 & 3 & & & & & \\
\hline & & Min. temp. & & -7.88 & 10.23 & -0.77 & -0.17 & 1.7 & 4 & & & & & \\
\hline & $10 t a 1$ & R.H.\% & 1310.24 & -23.1 & 5.97 & $-3.87^{* *}$ & -0.66 & 42.86 & 1 & 3.99 & 0.00 & 0.00 & 0.40 & 45.05 \\
\hline & & Dew Point & & 36.82 & 12.55 & $2.93^{* *}$ & 0.56 & 24.61 & 2 & & & & & \\
\hline & & Max. temp. & & 29 & 10.27 & $2.83^{*}$ & 0.54 & 21.31 & 4 & & & & & \\
\hline & Pre- & Min. temp. & $109493 *$ & -111.16 & 30.97 & $-3.59 * *$ & -0.64 & 34.39 & 1 & $461 * *$ & 082 & 07 & 049 & 4927 \\
\hline & adults & R.H.\% & & -31.61 & 10.09 & $-3.13^{* *}$ & -0.58 & 26.2 & 2 & & & & & \\
\hline & & Dew Point & & 97.94 & 33.14 & $2.96^{* *}$ & 0.56 & 23.31 & 3 & & & & & \\
\hline & & Max. temp. & & -0.8 & 0.84 & -0.95 & -0.21 & 3.28 & 4 & & & & & \\
\hline & Adult & Min. temp. & & 5.27 & 2.54 & 2.08 & 0.43 & 15.65 & 2 & & & & & \\
\hline & males & R.H.\% & -00.11 & 1.74 & 0.83 & $2.11^{*}$ & 0.44 & 16.13 & 1 & $2.1 \mathrm{~T}$ & 0.31 & 0.00 & 0.51 & $31.0 \mathrm{~T}$ \\
\hline Second Year & & Dew Point & & -4.63 & 2.72 & -1.71 & -0.36 & 10.57 & 3 & & & & & \\
\hline (2017/2018) & & Max. temp. & & -2.53 & 1.12 & $-2.25^{*}$ & -0.46 & 17.93 & 1 & & & & & \\
\hline & Gravid & Min. temp. & & -1.91 & 3.38 & -0.57 & -0.13 & 1.13 & 4 & & & & & \\
\hline & males & R.H.\% & 100.07 & -1.94 & 1.1 & -1.76 & -0.37 & 10.9 & 2 & 2.05 & (2. & 0.07 & 0.03 & 52.03 \\
\hline & & Dew Point & & 4.62 & 3.62 & 1.28 & 0.28 & 5.76 & 3 & & & & & \\
\hline & & Max. temp. & & 25.68 & 9.38 & $2.74^{*}$ & 0.53 & 19.1 & 4 & & & & & \\
\hline & & Min. temp. & & -107.8 & 28.3 & $-3.81^{* *}$ & -0.66 & 36.99 & 1 & 506 & 064 & 7 72 & 052 & 5156 \\
\hline & 10 & R.H.\% & 1100.20 & -31.8 & 9.22 & $-3.45^{* *}$ & -0.62 & 30.33 & 2 & 0.00 & 0.04 & 0.12 & 0.52 & 51.50 \\
\hline & & Dew Point & & 97.92 & 30.29 & $3.23^{* *}$ & 0.6 & 26.65 & 3 & & & & & \\
\hline
\end{tabular}

P. reg.= Partial regression; MR= Multiple correlation; S.E=Standard error; $\mathrm{P}$. cor.=Partial correlation; $\mathrm{R}^{2}=\mathrm{Coefficient}$ of determination; ${ }^{*}$ Significant at $\mathrm{P} \leq 0.05 ; \mathrm{C} . \mathrm{V} .=$ Coefficient of Variation; E.V\%= Explained variance; ${ }^{*}$ Highly Significant at $\mathrm{P} \leq 0.01$

D- Effect of mean dew point: Regarding the data in Table 1 showed that, the effect of mean dew point on pre-adults population was insignificantly negative and feeble ( $r$ values were -0.02 and -0.05), the calculated regression coefficient (b) for the effect of this factor indicated that for every $1^{\circ} \mathrm{C}$ increase, the population would decrease by 0.43 and 1.44 individuals per branch during the first and second years, respectively (Table 1 ). The exactly re- lationship between this climatic factor and the activity of the preadults was determined by the partial regression values (Table 2), which emphasized significant positive relation between mean dew point and the pre-adults activity (P. reg. was +38.86$)$, the value of the partial correlation was $(+0.54)$ and $(t)$ value was $(+2.81)$ in the first year (2016/2017) and a highly significant positive (P. reg. value was +97.94$)$, the partial correlation was $(+0.56)$ and $(\mathrm{t}$-test) 
value was (+2.96) during the second year (2017/2018), when the mean daily maximum temperature, minimum temperature and relative humidity become around their means (Table 2). The obtained results showed that, mean dew point under the optimum range of the pre-adults activity in the first year (2016/2017) and entirely under the optimum range of the pre-adults population during the second year $(2017 / 2018)$ and this climatic factor was responsible for the certain changes in the pre-adults population by 23.10 and $23.31 \%$ during the first and second years, respectively.

The combined effect of the tested climatic factors on the pre-adults activity: The combined effect of these climatic factors on the pre-adults population was significant for the first year (2016/2017) and a highly significant through the second year $(2017 / 2018)$ where the «F» values were 3.77 and 4.61 during the two years, respectively in Table 2 . The percentage of variability that could be attributed to the combined effect of these tested factors on the insect population which were 44.25 and $49.27 \%$ for the two years, respectively.

\section{Adult females population}

Effect of daily mean maximum temperature: Results are represented in Table 1 showed that the simple correlation (r) between the daily mean maximum temperature and the population density of adult females was insignificant positive $(+0.28$ and +0.13 ) during the first and second years, respectively. As well as, the calculated regression coefficient (b) for the effect of this factor indicated that every $1{ }^{\circ} \mathrm{C}$ increase in the daily mean maximum temperature, would increase the population by 0.29 and 0.13 individuals per branch for the both years, respectively (Table 1). The precise effect of this factor on the adult females population (Table 2) showed that it was insignificant effect and positive relation (P. reg. value was +2.80 ), the value of the partial correlation was $(+0.43)$ and $(t)$ value was $(+2.07)$ for the first year and insignificant negative for the second year (P. reg. was -0.80). Also, the value of partial correlation was $(-0.21)$ and the value of $t$-test was $(-0.95)$ when the mean daily minimum temperature, mean relative humidity and dew point become around their means. The obtained results revealed that, daily mean temperature within the optimum range of adult females activity for the first year and around the optimum range of adult females population during the second year. This climatic factor was responsible for the certain changes in the population of adult females by 14.13 and $3.28 \%$ during the two years, respectively (Table 2).

Effect of daily mean minimum temperature: The results of statistical analysis of simple correlation in Table 1 showed positive relation and insignificant effect between the daily mean minimum temperature and adult females population ( $\mathrm{r}$ values were +0.26 and +0.20 ) during the two years of study, respectively. The unit effect regression coefficient (b) indicates that an increase of $1{ }^{\circ} \mathrm{C}$ in the daily mean minimum temperature, would increase the population by 0.26 and 0.21 individuals per branch in the two years, respectively (Table 1 ). Concerning, the partial regression values are represented in Table 2, emphasized an insignificant positive relation $(+0.31$ and +5.27$)$, the values of partial correlation were $(+0.08$ and +0.43$)$ and $t$-test $)$ values were $(+0.37$ and +2.08$)$ in the two years, respectively, when the mean daily maximum temperature, relative humidity and dew point become around their means. The obtained results revealed that, daily mean minimum temperature within the optimum range of the adult females activity in the both years. This factor was the least effective variable in changes of the adult females population by $0.45 \%$ during the first year and was responsible for the certain changes in the population by $15.65 \%$ during the second years, respectively (Table 2).

Effect of the mean relative humidity: As shown in Table 1, it was noticed a insignificant negative effect between this climatic factor and the adult females population ( $r$ value was -0.05 ) in the first year and insignificant positive correlation ( $r$ value was +0.07 ) for the second year. In the same time, the simple regression coefficient indicates that an increase of $1 \%$ in the mean relative humidity, would decrease the population by 0.03 individuals per branch through the first year and would increase the population by 0.04 individuals per branch, for the second year (Table 1). The real effect of this factor appeared from the partial regression values that, referred to the significant positive effect (P. reg. values were +1.37 and +1.74$)$, the values of the partial correlation were $(+0.54$ and +0.44$)$ and t-test values were $(+2.83$ and +2.11$)$ for the $1^{\text {st }}$ and $2^{\text {nd }}$ years, respectively, when the mean daily maximum temperature, minimum temperature and dew point become around their means. Results revealed that, mean relative humidity was under the optimum range of adult females activity and this climatic factor was the most effective climatic variable in population changes of the adult females by 26.46 and $16.13 \%$ during the both years, respectively (Table 2).

Effect of mean dew point: Data in Table 1 obtained that, the effect of mean dew point on adult females activity was insignificantly positive $(+0.32$ and +0.33$)$, the calculated regression coefficient (b) for the effect of this factor indicated that for every $1^{\circ} \mathrm{C}$ increase, the population would increase by 0.61 and 0.65 individuals per branch during the first and second years, respectively.

The partial regression coefficient for the effect of mean dew point on the adult females population are represented in Table 2, revealed that it was insignificant negative relation (P. reg. values were -1.97 and -4.63$)$ and the values of the partial correlation were $(-0.40$ and -0.36$)$, also $(t)$ values were $(-1.93$ and -1.71$)$ during the both the two years, respectively, when the mean daily maximum temperature, minimum temperature and relative humidity become around their means. The obtained results revealed that, mean dew point was around the optimum range of adult females population and this climatic factor was responsible for the certain changes in the population of adult females by 12.31 and $10.57 \%$ during the two years, respectively (Table 2).

The combined effect of the tested climatic factors on the adult females: The results showed that the combined effect of these tested factors on the insect population of adult females was insignificant where the «F» values, were 2.81 and 2.14 during the two year respectively (Table 2). The multiple regression analysis 
revealed that the tested studied variables together were responsible of the changes in the adult females population. The percentages of explained variance were 37.20 and $31.04 \%$ for the two years, respectively.

\section{Gravid females' population}

Effect of daily mean maximum temperature: The results in Table 1, the correlation coefficient ( $\mathrm{r}$ ) between the daily mean maximum temperature and gravid females activity was feeble insignificant effect and positive relation $(+0.01)$ in the first year $(2016 / 2017)$ and negative relation (-0.07) during the second year (2017/2018). The unit effect regression coefficient (b) indicates that an increase of $1{ }^{\circ} \mathrm{C}$ in the daily mean maximum temperature, would increase the population by 0.02 individuals per branch for the first year and would decrease the population by 0.09 individuals per branch for the second year (Table 1).

Concerning, the partial regression values are represented in Table 2, emphasized an insignificant negative relation $(-1.77)$, the partial correlation was $(-0.22)$ and (t-test) value was $(-1.00)$ in the first year $(2016 / 2017)$ and it was a significant negative (P. reg. value was -2.53$)$, the partial correlation was -0.46$)$ and the value of t-test was (-2.25) during the second year (2017/2018), when the mean daily minimum temperature, relative humidity and dew point become around their means. The obtained results revealed that, daily mean maximum temperature around the optimum range of the gravid females activity in the first year (2016/2017) and above the optimum range of the gravid females population during the second year $(2017 / 2018)$ and this factor was responsible for the certain changes in the gravid females population by $4.28 \%$ during the first and was the most effective variable for the changes in the population by $17.93 \%$ during the second years (Table 2).

Effect of daily mean minimum temperature: Data in Table 1 showed the correlation coefficient ( $r$ ) between daily mean minimum temperature and the gravid females population was insignificant positive and weak $(+0.10$ and +0.03$)$ for the $1^{\text {st }}$ and $2^{\text {nd }}$ years, respectively. The calculated regression coefficient (b) for the effect of this factor indicated that for every $1{ }^{\circ} \mathrm{C}$ increase, the population would increase by 0.12 and 0.05 individuals per branch for two years of study, respectively (Table 1 ).

The precise effect of this factor on gravid females population revealed that, it was insignificant positive from the partial regression (P. reg. value $=+2.20$ ), the partial correlation was $(+0.42)$ and $t$ value was $(+2.02)$ in the first year $(2016 / 2017)$ and was insignificant negative effect (P. reg. value $=-1.91$ ), the partial correlation was $(-0.57)$ and the value of t-test was $(-0.13)$ during the second year $(2017 / 2018)$, when the mean daily maximum temperature, relative humidity and dew point become around their means (Table 2). The obtained results revealed that, mean minimum temperature was within the optimum range of gravid females activity in the first year and around the optimum range in the second year. This climatic factor was the most effective weather variable in changes of the gravid females population by $17.66 \%$ during the first year and was least effective variables during the second year by $1.13 \%$ (Table 2 ).

Effect of the mean relative humidity: As shown in Table 1, it was noticed a insignificant effect and feeble positive correlation between this climatic factor and the population density of gravid females ( $r$ value was +0.01 ) for the first year and insignificant negative ( $r$ value was -0.11 ) in the second year. In the same time, the simple regression coefficient indicates that an increase of $1 \%$ in the mean relative humidity, would increase the population by $0.01 \%$, for the first year and would decreased the population by $0.10 \%$ through the second year (Table 1 ). The exact effect of this factor appeared from the partial regression value that, referred to the insignificant positive effect (P. reg. value was +0.29 ), the values of the partial correlation was $(+0.11)$ and the value of t-test was (+0.46) during the first year $(2016 / 2017)$ and insignificant negative effect (P. reg. value was -1.94), the value of the partial correlation was $(-0.37)$ and the value of t-test was $(-1.76)$ during the second year (2017/2018), when the mean daily maximum temperature, minimum temperature and dew point become around their means (Table 2).

Results revealed that, mean relative humidity was within the optimum range of gravid females activity during the first year and around the optimum range during the second year and this climatic factor was the least effective variable for the changes in the population of gravid females by $0.92 \%$ for the first year and was responsible for the certain changes in the population by $10.90 \%$ during the second year (Table 2).

Effect of mean dew point: Data in Table 1 obtained that, the effect of mean dew point on the population activity of gravid females was insignificantly effect and feeble positive relation $(+0.03$ and +0.01 ) during the both years, respectively. The calculated regression coefficient (b) for the effect of this factor indicated that for every $1{ }^{\circ} \mathrm{C}$ increase, the population of gravid females would increase by 0.06 and 0.02 individuals per branch during the two years, respectively (Table 1 ). The partial regression coefficient for the effect of mean dew point on the population density of gravid females are represented in Table 2, revealed that it was insignificant negative effect and weak (P. reg. value $=-0.07$ ), the partial correlation was $(-0.01)$ and the value of t-test was (-0.05) during the first year (2016/2017) and it was insignificant positive effect (P. reg. value was +4.62$)$, the partial correlation was $(+0.28)$ and $t$ value was $(+1.28)$ in the second year $(2017 / 2018)$ and when the mean daily maximum temperature, minimum temperature and relative humidity become around their means (Table 2). The obtained results revealed that, mean dew point was around the optimum range of gravid females activity in the first year and within the optimum range in the second year. This climatic factor was the least effective weather variable in changes of the gravid females population by 0.01 and $5.76 \%$ during the two years, respectively (Table 2).

The combined effect of the tested climatic factors on the gravid females activity: The combined effect of these climatic factors on the population density of gravid females was insignif- 
icant where the «F» values, were 1.04 and 2.33 during the two years, respectively (Table 2). The percentage of variability that could be attributed to the combined effect of these tested factors on the activity of gravid females which were 18.00 and $32.89 \%$ for the two years, respectively (Table 2).

\section{Total population}

Effect of daily mean maximum temperature: As reported in Table 1, the correlation coefficient ( $\mathrm{r}$ ) between the mean daily temperature and total population of $W$. mimosae was insignificant positive $(+0.11$ and +0.23$)$ in the two years, respectively. The unit effect regression coefficient (b) indicates that an increase of $1{ }^{\circ} \mathrm{C}$ in the mean daily maximum temperature, would increase the population by 1.57 and 3.05 individuals per branch during the both years, respectively (Table 1).

The partial regression values emphasized an significant negative, relation was $(-39.47)$, the partial correlation was $(-0.48)$ and the value of " $t$ test " was (-2.36) for the first year (2016/2017) and it was a significant positive effect (P. reg. value was +25.68 ), the partial correlation was $(+0.53)$ and the value of t-test was $(+2.74)$ during the second year $(2017 / 2018)$, when the mean daily minimum temperature, relative humidity and dew point become around their means. The obtained results indicates that, daily mean maximum temperature above the optimum range of total population activity for the first year and under the optimum range of insect population during the second year and this climatic factor was responsible for the certain changes in the total insect population of by 15.97 and $19.10 \%$ during the two years, respectively in Table 2.

Effect of daily mean minimum temperature: Data in Table 1 showed the correlation coefficient ( $r$ ) between daily mean minimum temperature and the total population of pest was insignificant positive and weak $(+0.10$ and +0.12$)$ for the $1^{\text {st }}$ and $2^{\text {nd }}$ years, respectively. The calculated regression coefficient (b) for the effect of this factor indicated that for every $1{ }^{\circ} \mathrm{C}$ increase, the population would increase by 1.38 and 1.62 individuals per branch for two years of study, respectively (Table 1). The exact effect of this factor on insect population revealed that, it was insignificant negative from the partial regression (P. reg. value $=-7.88$ ), the partial correlation was $(-0.17)$ and $t$ value was $(-0.77)$ in the first year (2016/2017) and it was highly significant negative effect (P. reg. value was -107.80$)$ the partial correlation was $(-0.66)$ and $t$ value was $(-3.81)$ in the second year $(2017 / 2018)$, when the mean daily maximum temperature, relative humidity and dew point become around their means (Table 2). The obtained results revealed that, mean minimum temperature was around the optimum range of total population activity in the first year and was entirely above the optimum range of insect population activity during the second year. This climatic factor was the least effective variable in changes of the total population by $1.70 \%$ during the first year and was the most effective weather variable for the changes in insect population during the second year by $36.99 \%$ (Table 2).

Effect of the mean relative humidity: Results in Table 1 revealed that, the effect of this weather factor on total population of $W$. mimosae. The correlation coefficient ( $\mathrm{r}$ ) was insignificant relation and negative ( $\mathrm{r}$ values were -0.30 and -0.31 ) for the two years, respectively. The calculated regression coefficient (b) for the effect of this factor indicated that for every 1\% R.H. increase, the population would decrease by 2.47 and 2.79 individuals per branch for the both years, respectively (Table 1). The exactly relationship between this climatic factor and total population of pest was determined by the partial regression values (Table 2), which emphasized an highly significant negative during the two years. An increase of one degree in the mean relative humidity, would decrease the total population of pest by 23.10 and 31.80 individuals per branch provided that other three factors remain constant during the two years, respectively. Also, the values of the partial correlation were $(-0.66$ and -0.62$)$ and the values of $t$-test were $(-3.87$ and -3.45$)$ when the mean daily temperature and dew point become around their constant means during the two years, respectively in Table 2 . The obtained results revealed that, the mean relative humidity entirely above the optimum range of total population activity during the both years. This factor was the most effective variable in the insect population by $42.86 \%$ during the first year and was responsible for the certain changes in the population by $30.33 \%$ during the second year Table 2 .

Effect of mean dew point: Data in Table 1 showed that, the effect of mean dew point on total population activity was feeble insignificant effect and positive relation $(+0.01)$ in the first year $(2016 / 2017)$ and was insignificantly negative relation $(-0.03)$ during the second year $(2017 / 2018)$. The unit effect regression coefficient (b) indicates that an increase of $1{ }^{\circ} \mathrm{C}$ in the mean dew point, would increase the population by 0.25 individuals per branch for the first year and would decrease the population by 0.77 individuals per branch for the second year (Table 1).

The real relationship between this climatic factor and the activity of the insect population was determined by the partial regression values (Table 2), which emphasized highly significant positive relation in the both years. An increase of one degree in the mean dew point, would increase the population by 36.82 and 97.92 individuals per branch provided that other three factors remain constant during the two years, respectively. The values of the partial correlation were $(+0.56$ and +0.60$)$ and the values of t-test were $(+2.93$ and +3.23$)$ during the two years, respectively, when the daily mean maximum temperature, minimum temperature and relative humidity become around their constant means. The results revealed that, mean dew point was entirely under the optimum range of insect population activity and this climatic factor was the responsible for the certain changes in the total population density by 24.61 and $26.65 \%$ during the two years, respectively in Table 2 .

The combined effect of the tested climatic factors on the total population of $L$. tapleyi: The results in Table 2 showed that, the combined effect of these tested factors on the total population of $W$. mimosae was insignificant where the «F» value was 3.99 during the first year and highly significant where the «F» value was 5.06 during the second year, respectively. The amount of variability that could be attributed to the combined 
effect of the tested factors on the total population of insect were 45.65 and $51.56 \%$ for the two years, respectively. The remaining unexplained variances are assumed to be due to the influences of other undetermined and unconsidered factors that were not included in this study in addition to the experimental error.

Prediction of different alive stages of W. mimosae: Furthermore, the most effective climatic factors, that could be used to predict different alive stages of $W$. mimosae, were daily mean maximum air temperature $\left(\mathrm{x}_{1}\right)$, minimum temperature $\left(\mathrm{x}_{2}\right)$, relative humidity $\left(\mathrm{x}_{3}\right)$ and dew point $\left(\mathrm{x}_{4}\right)$. Prediction equation for general, the preadults, adult females, gravid females and total population of $W$. mimosae were concluded according to the statistical analysis on basis the two cumulative years together and presented as follow:

a. For pre-adults population:

$Y=600.1+4.47 x_{1}-25.12 x_{2} * *-11.73 x_{3} *+15.17 x_{4}$ E.V. $=23.67 \%$

b. For adult females population:

$$
Y=-40.50+0.33 x_{1}+1.18 x_{2}+0.73 x_{3} *-0.69 x_{4} \text { E.V. }=21.98 \%
$$

C. For gravid females population:

$$
Y=71.02 *-2.53 x_{1} * *+1.54 x_{2}-0.49 x_{3}+0.81 x_{4} E . V .=18.54 \%
$$

d. For total population of pest:

$Y=630.63 *+2.27 x_{1}-22.40 x_{2} *-11.49 x_{3} * *+15.83 x_{4}$ E.V. $=24.38 \%$

Where is, $\mathrm{Y}=$ Prediction value. E.V.\% = Explained variance

*Significant at $\mathrm{P} \leq 0.05{ }^{* *}$ Highly significant at $\mathrm{P} \leq 0.01$
The aforementioned results on the effect of tested weather factors on the insect population of $W$. mimosae during the two successive years emphasize that the effect of these factors varied from year to another. Also, the mean of relative humidity and dew point during the first year $(2016 / 2017)$ and the daily mean minimum air temperature and mean of relative humidity through the second year $(2017 / 2018)$ was the most effective variables for the changes in the total insect population.

\section{Effect of the biotic factor (Ants density) on the activity} of different stages of $W$. mimosae population

\section{Impact of ant exclusion versus ant presence on the population density of different stages of W. mimosae on sunt trees}

The impact of foraging ants, Messon sp. (Hymenoptera: Formicidae) on the population size of the honeydew-producing wax scale insect, $W$. mimosae on sunt trees were carried out at Esna district, Luxor Governorate during the two successive years through the period from September $10^{\text {th }}, 2016$ up to August $25^{\text {th }}$, 2018 are represented in Table 3 \& 4 and graphically illustrated in Figure 2. The trends of fluctuation in the numbers of insect population of W. mimosae between branches of sunt trees with and without ants were almost similar, however, with different values. Accordingly, its better to discuss the seasonal activity on the basis of monthly mean number of insect population counts per branch in trees containing ants and in trees which ants were excluded at the successive sampling dates.

Table 3: Simple correlation and regression values when the counts of the climatic factors were plotted versus the population density of different

\begin{tabular}{|c|c|c|c|c|c|c|c|c|c|c|c|c|c|c|c|}
\hline \multirow{3}{*}{$\begin{array}{l}\text { Sea- } \\
\text { sons }\end{array}$} & \multicolumn{15}{|c|}{ Mean Number of Individuals per Branch \pm S.E. } \\
\hline & \multicolumn{8}{|c|}{ Ant Presence } & \multicolumn{7}{|c|}{ Ant Exclusion } \\
\hline & & $\begin{array}{c}\text { First } \\
\text { Instar } \\
\text { Nymphs }\end{array}$ & $\begin{array}{l}\text { Second } \\
\text { Instar } \\
\text { Nymphs }\end{array}$ & $\begin{array}{c}\text { Third } \\
\text { Instar } \\
\text { Nymphs }\end{array}$ & $\begin{array}{l}\text { Pre- } \\
\text { adults } \\
\text { Total }\end{array}$ & $\begin{array}{c}\text { Adult } \\
\text { Fe- } \\
\text { males }\end{array}$ & $\begin{array}{c}\text { Gravid } \\
\text { Fe- } \\
\text { males }\end{array}$ & Total & $\begin{array}{c}\text { First } \\
\text { Instar } \\
\text { Nymphs }\end{array}$ & $\begin{array}{c}\text { Second } \\
\text { Instar } \\
\text { Nymphs }\end{array}$ & $\begin{array}{c}\text { Third } \\
\text { Instar } \\
\text { Nymphs }\end{array}$ & $\begin{array}{c}\text { Pre- } \\
\text { adults } \\
\text { Total }\end{array}$ & $\begin{array}{c}\text { Adult } \\
\text { Fe- } \\
\text { males }\end{array}$ & $\begin{array}{c}\text { Grav- } \\
\text { id } \\
\text { Fe- } \\
\text { males }\end{array}$ & Total \\
\hline \multirow{3}{*}{$\begin{array}{l}\text { Au- } \\
\text { tumn }\end{array}$} & $\begin{array}{l}\text { Sept., } \\
2016\end{array}$ & $\begin{array}{c}3.00 \pm \\
0.16\end{array}$ & 0 & 0 & $\begin{array}{c}3.00 \pm \\
0.16\end{array}$ & $\begin{array}{c}7.50 \pm \\
0.41\end{array}$ & $\begin{array}{c}25.00 \pm \\
1.36\end{array}$ & $\begin{array}{c}35.50 \pm \\
1.93\end{array}$ & $\begin{array}{c}1.50 \pm \\
0.08\end{array}$ & 0 & 0 & $\begin{array}{c}1.50 \pm \\
0.08\end{array}$ & $\begin{array}{c}5.10 \pm \\
0.28\end{array}$ & $\begin{array}{l}12.20 \\
\pm 0.66\end{array}$ & $\begin{array}{r}18.80 \\
\pm 1.02\end{array}$ \\
\hline & Oct. & $\begin{array}{c}185.28 \pm \\
9.93\end{array}$ & $\begin{array}{c}6.50 \pm \\
0.35\end{array}$ & $\begin{array}{c}2.00 \pm \\
0.11\end{array}$ & $\begin{array}{r}193.78 \\
\pm 10.39\end{array}$ & $\begin{array}{c}3.00 \pm \\
0.16\end{array}$ & $\begin{array}{c}5.50 \pm \\
0.30\end{array}$ & $\begin{array}{r}202.28 \\
\pm 10.85\end{array}$ & $\begin{array}{c}102.86 \pm \\
5.51\end{array}$ & $\begin{array}{c}3.43 \pm \\
0.91\end{array}$ & $\begin{array}{c}1.04 \pm \\
0.06\end{array}$ & $\begin{array}{c}107.33 \\
\pm 5.75\end{array}$ & $\begin{array}{c}2.09 \pm \\
0.11\end{array}$ & $\begin{array}{c}3.86 \pm \\
0.21\end{array}$ & $\begin{array}{l}113.27 \\
\pm 6.07\end{array}$ \\
\hline & Nov. & $\begin{array}{c}125.26 \pm \\
6.80\end{array}$ & $\begin{array}{c}97.68 \pm \\
5.23\end{array}$ & $\begin{array}{c}17.00 \pm \\
0.93\end{array}$ & $\begin{array}{r}239.94 \\
\pm 12.96\end{array}$ & 0 & $\begin{array}{c}0.50 \pm \\
0.03\end{array}$ & $\begin{array}{r}240.44 \\
\pm 12.98\end{array}$ & $\begin{array}{c}65.14 \pm \\
3.54\end{array}$ & $\begin{array}{c}50.79 \pm \\
2.72\end{array}$ & $\begin{array}{c}8.84 \pm \\
0.48\end{array}$ & $\begin{array}{l}124.77 \\
\pm 6.74\end{array}$ & 0 & $\begin{array}{c}0.33 \pm \\
0.02\end{array}$ & $\begin{array}{l}125.09 \\
\pm 6.76\end{array}$ \\
\hline \multicolumn{2}{|c|}{ Average } & $\begin{array}{c}104.51 \pm \\
18.58\end{array}$ & $\begin{array}{c}34.73 \pm \\
9.78\end{array}$ & $\begin{array}{c}6.33 \pm \\
1.72\end{array}$ & $\begin{array}{r}145.57 \\
\pm 23.19\end{array}$ & $\begin{array}{c}3.50 \pm \\
0.68\end{array}$ & $\begin{array}{c}10.33 \pm \\
2.27\end{array}$ & $\begin{array}{r}159.40 \\
\pm 20.48\end{array}$ & $\begin{array}{c}56.50 \pm \\
9.85\end{array}$ & $\begin{array}{c}18.07 \pm \\
5.08\end{array}$ & $\begin{array}{c}3.29 \pm \\
0.90\end{array}$ & $\begin{array}{c}77.86 \\
\pm \\
12.05\end{array}$ & $\begin{array}{c}2.40 \pm \\
0.46\end{array}$ & $\begin{array}{c}5.46 \pm \\
1.08\end{array}$ & $\begin{array}{c}85.72 \\
\pm \\
10.63\end{array}$ \\
\hline \multirow{3}{*}{ Winter } & Dec. & $\begin{array}{c}12.50 \pm \\
0.68\end{array}$ & $\begin{array}{c}57.13 \pm \\
3.03\end{array}$ & $\begin{array}{c}23.00 \pm \\
1.25\end{array}$ & $\begin{array}{c}92.63 \pm \\
4.96\end{array}$ & $\begin{array}{c}7.00 \pm \\
0.38\end{array}$ & 0 & $\begin{array}{c}99.63 \pm \\
5.34\end{array}$ & $\begin{array}{c}6.70 \pm \\
0.36\end{array}$ & $\begin{array}{c}31.79 \pm \\
1.69\end{array}$ & $\begin{array}{c}12.74 \pm \\
0.69\end{array}$ & $\begin{array}{l}51.22 \\
\pm 2.75\end{array}$ & $\begin{array}{c}4.00 \pm \\
0.22\end{array}$ & 0 & $\begin{array}{l}55.22 \\
\pm 2.96\end{array}$ \\
\hline & $\begin{array}{l}\text { Jan., } \\
2017\end{array}$ & 0 & 0 & $\begin{array}{c}1.50 \pm \\
0.08\end{array}$ & $\begin{array}{c}1.50 \pm \\
0.08\end{array}$ & $\begin{array}{c}15.75 \pm \\
0.71\end{array}$ & $\begin{array}{c}5.01 \pm \\
0.26\end{array}$ & $\begin{array}{c}22.26 \pm \\
1.05\end{array}$ & 0 & 0 & $\begin{array}{c}0.98 \pm \\
0.05\end{array}$ & $\begin{array}{c}0.98 \pm \\
0.05\end{array}$ & $\begin{array}{c}8.51 \pm \\
0.39\end{array}$ & $\begin{array}{c}3.06 \pm \\
0.16\end{array}$ & $\begin{array}{l}12.54 \\
\pm 0.60\end{array}$ \\
\hline & Feb. & 0 & 0 & 0 & 0 & $\begin{array}{c}6.66 \pm \\
0.28\end{array}$ & $\begin{array}{c}13.26 \pm \\
0.68\end{array}$ & $\begin{array}{c}19.93 \pm \\
0.95\end{array}$ & 0 & 0 & 0 & 0 & $\begin{array}{c}3.89 \pm \\
0.16\end{array}$ & $\begin{array}{c}4.59 \pm \\
0.24\end{array}$ & $\begin{array}{c}8.48 \pm \\
0.39\end{array}$ \\
\hline \multicolumn{2}{|c|}{ Average } & $\begin{array}{c}4.17 \pm \\
1.69\end{array}$ & $\begin{array}{c}19.04 \pm \\
6.41\end{array}$ & $\begin{array}{c}8.17 \pm \\
2.58\end{array}$ & $\begin{array}{c}31.38 \pm \\
10.63\end{array}$ & $\begin{array}{c}9.80 \pm \\
1.03\end{array}$ & $\begin{array}{c}6.09 \pm \\
1.21\end{array}$ & $\begin{array}{c}47.27 \pm \\
9.36\end{array}$ & $\begin{array}{c}2.23 \pm \\
0.88\end{array}$ & $\begin{array}{c}10.60 \pm \\
3.41\end{array}$ & $\begin{array}{c}4.57 \pm \\
1.36\end{array}$ & $\begin{array}{l}17.40 \\
\pm 5.61\end{array}$ & $\begin{array}{c}5.46 \pm \\
0.52\end{array}$ & $\begin{array}{c}2.55 \pm \\
0.46\end{array}$ & $\begin{array}{l}25.41 \\
\pm 5.03\end{array}$ \\
\hline
\end{tabular}
stages of $W$. mimosae during the two successive years of (2016 to 2018). 


\section{Agricultural Research \& Technology: Open Access Journal}

\begin{tabular}{|c|c|c|c|c|c|c|c|c|c|c|c|c|c|c|c|}
\hline \multirow{3}{*}{ Spring } & Mar. & $\begin{array}{c}7.55 \pm \\
0.40\end{array}$ & $\begin{array}{c}1.00 \pm \\
0.05\end{array}$ & 0 & $\begin{array}{c}8.55 \pm \\
0.46\end{array}$ & $\begin{array}{c}1.53 \pm \\
0.10\end{array}$ & $\begin{array}{c}15.26 \pm \\
0.68\end{array}$ & $\begin{array}{c}25.34 \pm \\
1.22\end{array}$ & $\begin{array}{c}7.05 \pm \\
0.38\end{array}$ & $\begin{array}{c}0.92 \pm \\
0.05\end{array}$ & 0 & $\begin{array}{c}7.97 \pm \\
0.43\end{array}$ & $\begin{array}{c}1.51 \pm \\
0.10\end{array}$ & $\begin{array}{l}12.94 \\
\pm 0.58\end{array}$ & $\begin{array}{l}22.43 \\
\pm 1.09\end{array}$ \\
\hline & April & $\begin{array}{c}156.13 \pm \\
8.42\end{array}$ & $\begin{array}{c}40.25 \pm \\
2.03\end{array}$ & $\begin{array}{c}1.01 \pm \\
0.05\end{array}$ & $\begin{array}{r}197.39 \\
\pm 10.49\end{array}$ & 0 & $\begin{array}{c}10.13 \pm \\
0.48\end{array}$ & $\begin{array}{r}207.51 \\
\pm 10.96\end{array}$ & $\begin{array}{c}101.48 \pm \\
5.47\end{array}$ & $\begin{array}{c}26.16 \pm \\
1.32\end{array}$ & $\begin{array}{c}0.66 \pm \\
0.03\end{array}$ & $\begin{array}{l}128.30 \\
\pm 6.82\end{array}$ & $\begin{array}{c}0.50 \pm \\
0.29\end{array}$ & $\begin{array}{c}6.08 \pm \\
0.29\end{array}$ & $\begin{array}{l}134.88 \\
\pm 7.17\end{array}$ \\
\hline & May & $\begin{array}{c}97.65 \pm \\
5.25\end{array}$ & $\begin{array}{c}102.73 \pm \\
5.48\end{array}$ & $\begin{array}{c}25.00 \pm \\
1.36\end{array}$ & $\begin{array}{r}225.38 \\
\pm 12.08\end{array}$ & 0 & $\begin{array}{c}4.50 \pm \\
0.25\end{array}$ & $\begin{array}{r}229.88 \\
\pm 12.33\end{array}$ & $\begin{array}{c}63.47 \pm \\
3.41\end{array}$ & $\begin{array}{c}66.77 \pm \\
3.56\end{array}$ & $\begin{array}{c}16.25 \pm \\
0.89\end{array}$ & $\begin{array}{l}146.49 \\
\pm 7.85\end{array}$ & 0 & $\begin{array}{c}2.95 \pm \\
0.16\end{array}$ & $\begin{array}{l}149.44 \\
\pm 8.02\end{array}$ \\
\hline \multicolumn{2}{|c|}{ Average } & $\begin{array}{c}87.11 \pm \\
13.65\end{array}$ & $\begin{array}{c}47.99 \pm \\
9.66\end{array}$ & $\begin{array}{c}8.67 \pm \\
3.18\end{array}$ & $\begin{array}{r}143.77 \\
\pm 21.42\end{array}$ & $\begin{array}{c}0.51 \pm \\
0.16\end{array}$ & $\begin{array}{c}9.96 \pm \\
1.02\end{array}$ & $\begin{array}{r}154.24 \\
\pm 20.50\end{array}$ & $\begin{array}{c}57.34 \pm \\
8.70\end{array}$ & $\begin{array}{c}31.28 \pm \\
6.26\end{array}$ & $\begin{array}{c}5.64 \pm \\
2.07\end{array}$ & $\begin{array}{c}94.26 \\
\pm \\
13.71\end{array}$ & $\begin{array}{c}0.67 \pm \\
0.16\end{array}$ & $\begin{array}{c}7.32 \pm \\
0.93\end{array}$ & $\begin{array}{c}102.25 \\
\pm \\
12.77\end{array}$ \\
\hline \multirow{3}{*}{$\begin{array}{l}\text { Sum- } \\
\text { mer }\end{array}$} & June & $\begin{array}{c}13.00 \pm \\
0.71\end{array}$ & $\begin{array}{c}40.00 \pm \\
2.18\end{array}$ & $\begin{array}{c}93.25 \pm \\
5.04\end{array}$ & $\begin{array}{l}146.25 \\
\pm 7.92\end{array}$ & $\begin{array}{c}6.63 \pm \\
0.29\end{array}$ & 0 & $\begin{array}{l}152.88 \\
\pm 8.20\end{array}$ & $\begin{array}{c}8.45 \pm \\
0.46\end{array}$ & $\begin{array}{c}26.00 \pm \\
1.42\end{array}$ & $\begin{array}{c}60.61 \pm \\
3.27\end{array}$ & $\begin{array}{r}95.06 \\
\pm 5.15\end{array}$ & $\begin{array}{c}5.44 \pm \\
0.24\end{array}$ & 0 & $\begin{array}{l}100.50 \\
\pm 5.38\end{array}$ \\
\hline & July & 0 & $\begin{array}{c}1.00 \pm \\
0.15\end{array}$ & $\begin{array}{c}34.00 \pm \\
1.85\end{array}$ & $\begin{array}{c}35.00 \pm \\
1.91\end{array}$ & $\begin{array}{c}14.00 \pm \\
0.76\end{array}$ & 0 & $\begin{array}{c}49.00 \pm \\
2.67\end{array}$ & 0 & $\begin{array}{c}0.65 \pm \\
0.04\end{array}$ & $\begin{array}{c}23.72 \pm \\
1.29\end{array}$ & $\begin{array}{r}24.37 \\
\pm 1.33 \\
\end{array}$ & $\begin{array}{r}10.86 \\
\pm 0.59\end{array}$ & 0 & $\begin{array}{r}35.23 \\
\pm 1.92\end{array}$ \\
\hline & Aug. & 0 & 0 & $\begin{array}{c}5.00 \pm \\
0.27\end{array}$ & $\begin{array}{c}5.00 \pm \\
0.27\end{array}$ & $\begin{array}{c}20.50 \pm \\
1.12\end{array}$ & $\begin{array}{c}12.00 \pm \\
0.65\end{array}$ & $\begin{array}{c}37.50 \pm \\
2.04\end{array}$ & 0 & 0 & $\begin{array}{c}5.20 \pm \\
0.27\end{array}$ & $\begin{array}{c}5.20 \pm \\
0.27\end{array}$ & $\begin{array}{l}13.12 \\
\pm 0.71\end{array}$ & $\begin{array}{c}7.92 \pm \\
0.43\end{array}$ & $\begin{array}{l}26.24 \\
\pm 1.40\end{array}$ \\
\hline \multicolumn{2}{|c|}{ Total } & 1200.73 & 692.55 & 403.53 & 2296.8 & 165.13 & 182.33 & 2644.26 & 356.64 & 206.51 & 130.03 & 693.18 & 55.02 & 53.92 & 802.12 \\
\hline \multicolumn{2}{|c|}{$\begin{array}{l}\text { General } \\
\text { average }\end{array}$} & $\begin{array}{c}50.03 \pm \\
7.41\end{array}$ & $\begin{array}{c}28.86 \pm \\
4.19\end{array}$ & $\begin{array}{c}16.81 \pm \\
2.82\end{array}$ & $\begin{array}{c}95.70 \pm \\
10.21\end{array}$ & $\begin{array}{c}6.88 \pm \\
0.71\end{array}$ & $\begin{array}{c}7.60 \pm \\
0.81\end{array}$ & $\begin{array}{l}110.18 \\
\pm 9.39\end{array}$ & $\begin{array}{c}29.72 \pm \\
4.28\end{array}$ & $\begin{array}{c}17.21 \pm \\
2.49\end{array}$ & $\begin{array}{c}10.84 \pm \\
1.82\end{array}$ & $\begin{array}{r}57.77 \\
\pm 5.99\end{array}$ & $\begin{array}{c}4.58 \pm \\
0.45\end{array}$ & $\begin{array}{c}4.49 \pm \\
0.47\end{array}$ & $\begin{array}{r}66.84 \\
\pm 5.53\end{array}$ \\
\hline \multicolumn{2}{|c|}{$\%$} & 45.41 & 26.19 & 15.26 & 86.86 & 6.24 & 6.9 & 100 & 44.46 & 25.75 & 16.21 & 86.42 & 6.86 & 6.72 & 100 \\
\hline
\end{tabular}

For each stage of pest, means for population density of W. mimosae among the untreated (ant presence) and treated trees (ant exclusion) with the pesticide were compared using paired T-test.

Table 4: Impact of ants exclusion versus ants presence on the population density of different stages of W. mimosae on sunt trees at Esna district, Luxor Governorate during the second year of (2017/2018).

\begin{tabular}{|c|c|c|c|c|c|c|c|c|c|c|c|c|c|c|c|}
\hline \multirow{3}{*}{$\begin{array}{l}\text { Sea- } \\
\text { sons }\end{array}$} & \multicolumn{15}{|c|}{ Mean Number of Individuals per Branch \pm S.E. } \\
\hline & \multicolumn{8}{|c|}{ Ant Presence } & \multicolumn{7}{|c|}{ Ant Exclusion } \\
\hline & & $\begin{array}{c}\text { First } \\
\text { Instar } \\
\text { Nymphs }\end{array}$ & $\begin{array}{l}\text { Second } \\
\text { Instar } \\
\text { Nymphs }\end{array}$ & $\begin{array}{c}\text { Third } \\
\text { Instar } \\
\text { Nymphs }\end{array}$ & $\begin{array}{c}\text { Pre- } \\
\text { adults } \\
\text { Total }\end{array}$ & $\begin{array}{c}\text { Adult } \\
\text { Fe- } \\
\text { males }\end{array}$ & $\begin{array}{c}\text { Gravid } \\
\text { Fe- } \\
\text { males }\end{array}$ & Total & $\begin{array}{c}\text { First } \\
\text { Instar } \\
\text { Nymphs }\end{array}$ & $\begin{array}{l}\text { Second } \\
\text { Instar } \\
\text { Nymphs }\end{array}$ & $\begin{array}{l}\text { Third } \\
\text { Instar } \\
\text { Nymphs }\end{array}$ & $\begin{array}{c}\text { Pre- } \\
\text { adults } \\
\text { Total }\end{array}$ & $\begin{array}{c}\text { Adult } \\
\text { Fe- } \\
\text { males }\end{array}$ & $\begin{array}{l}\text { Grav- } \\
\text { id Fe- } \\
\text { males }\end{array}$ & Total \\
\hline \multirow{3}{*}{$\begin{array}{l}\mathrm{Au}- \\
\text { tumn }\end{array}$} & $\begin{array}{l}\text { Sep, } \\
2017\end{array}$ & $\begin{array}{c}3.39 \pm \\
0.18\end{array}$ & 0 & 0 & $\begin{array}{c}3.39 \pm \\
0.18\end{array}$ & $\begin{array}{c}9.30 \pm \\
0.45\end{array}$ & $\begin{array}{c}27.19 \pm \\
1.48\end{array}$ & $\begin{array}{c}39.88 \pm \\
2.11\end{array}$ & $\begin{array}{c}1.43 \pm \\
0.08\end{array}$ & 0 & 0 & $\begin{array}{c}1.43 \pm \\
0.08\end{array}$ & $\begin{array}{c}5.80 \pm \\
0.28\end{array}$ & $\begin{array}{r}12.24 \\
\pm 0.67\end{array}$ & $\begin{array}{r}19.46 \\
\pm 1.02\end{array}$ \\
\hline & Oct. & $\begin{array}{c}229.06 \pm \\
12.48\end{array}$ & $\begin{array}{c}9.50 \pm \\
0.52\end{array}$ & $\begin{array}{c}3.00 \pm \\
0.16\end{array}$ & $\begin{array}{c}241.56 \pm \\
13.16\end{array}$ & $\begin{array}{c}3.77 \pm \\
0.21\end{array}$ & $\begin{array}{c}6.98 \pm \\
0.38\end{array}$ & $\begin{array}{l}252.30 \\
\pm 13.74\end{array}$ & $\begin{array}{c}122.57 \pm \\
6.68\end{array}$ & $\begin{array}{c}4.84 \pm \\
0.26\end{array}$ & $\begin{array}{c}1.48 \pm \\
0.08\end{array}$ & $\begin{array}{l}128.88 \\
\pm 7.02\end{array}$ & $\begin{array}{c}2.42 \pm \\
0.13\end{array}$ & $\begin{array}{c}4.00 \pm \\
0.22\end{array}$ & $\begin{array}{l}135.31 \\
\pm 7.37\end{array}$ \\
\hline & Nov. & $\begin{array}{c}115.00 \pm \\
6.26\end{array}$ & $\begin{array}{c}78.33 \pm \\
4.27\end{array}$ & $\begin{array}{c}14.52 \pm \\
0.79\end{array}$ & $\begin{array}{c}207.84 \pm \\
11.32\end{array}$ & 0 & $\begin{array}{c}0.55 \pm \\
0.03\end{array}$ & $\begin{array}{l}208.39 \\
\pm 11.35\end{array}$ & $\begin{array}{c}56.81 \pm \\
3.09\end{array}$ & $\begin{array}{c}38.69 \pm \\
2.11\end{array}$ & $\begin{array}{c}7.17 \pm \\
0.39\end{array}$ & $\begin{array}{l}102.67 \\
\pm 5.59\end{array}$ & 0 & $\begin{array}{c}0.36 \pm \\
0.02\end{array}$ & $\begin{array}{l}103.03 \\
\pm 5.61\end{array}$ \\
\hline \multicolumn{2}{|c|}{ Average } & $\begin{array}{c}115.82 \pm \\
20.53\end{array}$ & $\begin{array}{c}29.28 \pm \\
8.03\end{array}$ & $\begin{array}{c}5.84 \pm \\
1.48\end{array}$ & $\begin{array}{c}150.93 \pm \\
22.84\end{array}$ & $\begin{array}{c}4.36 \pm \\
0.87\end{array}$ & $\begin{array}{c}11.57 \pm \\
2.45\end{array}$ & $\begin{array}{l}166.86 \\
\pm 20.00\end{array}$ & $\begin{array}{c}60.27 \pm \\
10.80\end{array}$ & $\begin{array}{c}14.51 \pm \\
3.96\end{array}$ & $\begin{array}{c}2.88 \pm \\
0.73\end{array}$ & $\begin{array}{c}77.66 \pm \\
11.71\end{array}$ & $\begin{array}{c}2.74 \pm \\
0.53\end{array}$ & $\begin{array}{c}5.53 \pm \\
1.08\end{array}$ & $\begin{array}{c}85.93 \\
\pm \\
10.44\end{array}$ \\
\hline \multirow{3}{*}{ Winter } & Dec. & $\begin{array}{c}9.45 \pm \\
0.51\end{array}$ & $\begin{array}{c}52.40 \pm \\
2.85\end{array}$ & $\begin{array}{c}21.94 \pm \\
1.20\end{array}$ & $\begin{array}{c}83.79 \pm \\
4.56\end{array}$ & $\begin{array}{c}7.95 \pm \\
0.43\end{array}$ & 0 & $\begin{array}{c}91.74 \pm \\
5.00\end{array}$ & $\begin{array}{c}4.88 \pm \\
0.27\end{array}$ & $\begin{array}{c}28.16 \pm \\
1.53\end{array}$ & $\begin{array}{c}12.07 \pm \\
0.66\end{array}$ & $\begin{array}{c}45.11 \pm \\
2.46\end{array}$ & $\begin{array}{c}4.54 \pm \\
0.25\end{array}$ & 0 & $\begin{array}{l}49.65 \\
\pm 2.70\end{array}$ \\
\hline & $\begin{array}{l}\text { Jan., } \\
2018\end{array}$ & 0 & 0 & $\begin{array}{c}2.00 \pm \\
0.11\end{array}$ & $\begin{array}{c}2.00 \pm \\
0.11\end{array}$ & $\begin{array}{l}16.64 \\
\pm 0.91\end{array}$ & $\begin{array}{c}5.00 \pm \\
0.27\end{array}$ & $\begin{array}{c}23.64 \pm \\
1.29\end{array}$ & 0 & 0 & $\begin{array}{c}1.24 \pm \\
0.07\end{array}$ & $\begin{array}{c}1.24 \pm \\
0.07\end{array}$ & $\begin{array}{c}8.99 \pm \\
0.49\end{array}$ & $\begin{array}{c}3.08 \pm \\
0.17\end{array}$ & $\begin{array}{r}13.30 \\
\pm 0.72\end{array}$ \\
\hline & Feb. & 0 & 0 & 0 & 0 & $\begin{array}{c}5.46 \pm \\
0.30\end{array}$ & $\begin{array}{c}8.64 \pm \\
0.47\end{array}$ & $\begin{array}{c}14.10 \pm \\
0.77\end{array}$ & 0 & 0 & 0 & 0 & $\begin{array}{c}3.08 \pm \\
0.17\end{array}$ & $\begin{array}{c}2.81 \pm \\
0.15\end{array}$ & $\begin{array}{c}5.89 \pm \\
0.32\end{array}$ \\
\hline \multicolumn{2}{|c|}{ Average } & $\begin{array}{c}3.15 \pm \\
1.18\end{array}$ & $\begin{array}{c}17.47 \pm \\
5.52\end{array}$ & $\begin{array}{c}7.98 \pm \\
2.11\end{array}$ & $\begin{array}{c}28.60 \pm \\
8.68\end{array}$ & $\begin{array}{l}10.02 \\
\pm 1.12\end{array}$ & $\begin{array}{c}4.55 \pm \\
0.81\end{array}$ & $\begin{array}{c}43.16 \pm \\
7.68\end{array}$ & $\begin{array}{c}1.63 \pm \\
0.59\end{array}$ & $\begin{array}{c}9.39 \pm \\
2.86\end{array}$ & $\begin{array}{l}4.44 \pm \\
1.15\end{array}$ & $\begin{array}{c}15.45 \pm \\
4.51\end{array}$ & $\begin{array}{c}5.53 \pm \\
0.58\end{array}$ & $\begin{array}{c}1.96 \pm \\
0.32\end{array}$ & $\begin{array}{c}22.94 \\
\pm 4.10\end{array}$ \\
\hline \multirow{3}{*}{ Spring } & Mar. & $\begin{array}{c}13.47 \pm \\
0.73\end{array}$ & $\begin{array}{c}2.00 \pm \\
0.11\end{array}$ & 0 & $\begin{array}{c}15.47 \pm \\
0.84\end{array}$ & $\begin{array}{c}2.21 \pm \\
0.12\end{array}$ & $\begin{array}{c}23.58 \pm \\
1.28\end{array}$ & $\begin{array}{c}41.27 \pm \\
2.25\end{array}$ & $\begin{array}{c}11.72 \pm \\
0.64\end{array}$ & $\begin{array}{c}1.75 \pm \\
0.10\end{array}$ & 0 & $\begin{array}{c}13.46 \pm \\
0.73\end{array}$ & $\begin{array}{c}1.98 \pm \\
0.11\end{array}$ & $\begin{array}{r}13.53 \\
\pm 0.74\end{array}$ & $\begin{array}{l}28.98 \\
\pm 1.58\end{array}$ \\
\hline & April & $\begin{array}{c}182.02 \pm \\
9.92\end{array}$ & $\begin{array}{c}44.86 \pm \\
2.44\end{array}$ & $\begin{array}{c}1.10 \pm \\
0.06\end{array}$ & $\begin{array}{c}227.99 \pm \\
12.42\end{array}$ & 0 & $\begin{array}{c}19.22 \pm \\
1.05\end{array}$ & $\begin{array}{l}247.21 \\
\pm 13.47\end{array}$ & $\begin{array}{c}110.03 \pm \\
5.99\end{array}$ & $\begin{array}{c}27.12 \pm \\
1.48\end{array}$ & $\begin{array}{c}0.67 \pm \\
0.04\end{array}$ & $\begin{array}{l}137.82 \\
\pm 7.51\end{array}$ & 0 & $\begin{array}{c}8.07 \pm \\
0.44\end{array}$ & $\begin{array}{l}145.89 \\
\pm 7.95\end{array}$ \\
\hline & May & $\begin{array}{c}110.50 \pm \\
6.02\end{array}$ & $\begin{array}{c}98.71 \pm \\
5.38\end{array}$ & $\begin{array}{c}18.37 \pm \\
1.00\end{array}$ & $\begin{array}{c}227.58 \pm \\
12.40\end{array}$ & 0 & $\begin{array}{c}5.47 \pm \\
0.30\end{array}$ & $\begin{array}{r}233.06 \\
\pm 12.69\end{array}$ & $\begin{array}{c}66.80 \pm \\
3.64\end{array}$ & $\begin{array}{c}59.67 \pm \\
3.25\end{array}$ & $\begin{array}{c}11.10 \pm \\
0.60\end{array}$ & $\begin{array}{l}137.57 \\
\pm 7.49\end{array}$ & 0 & $\begin{array}{c}2.68 \pm \\
0.15\end{array}$ & $\begin{array}{r}140.25 \\
\pm 7.64\end{array}$ \\
\hline \multicolumn{2}{|c|}{ Average } & $\begin{array}{c}102.00 \pm \\
15.52\end{array}$ & $\begin{array}{c}48.53 \pm \\
9.45\end{array}$ & $\begin{array}{l}6.49 \pm \\
2.12\end{array}$ & $\begin{array}{c}157.02 \pm \\
22.61\end{array}$ & $\begin{array}{c}0.74 \pm \\
0.22\end{array}$ & $\begin{array}{c}16.09 \pm \\
1.84\end{array}$ & $\begin{array}{l}173.84 \\
\pm 21.46\end{array}$ & $\begin{array}{c}62.85 \pm \\
9.12\end{array}$ & $\begin{array}{c}29.51 \pm \\
5.68\end{array}$ & $\begin{array}{c}3.92 \pm \\
1.28\end{array}$ & $\begin{array}{c}96.29 \pm \\
13.33\end{array}$ & $\begin{array}{c}0.66 \pm \\
0.20\end{array}$ & $\begin{array}{c}8.09 \pm \\
1.04\end{array}$ & $\begin{array}{c}105.04 \\
\pm \\
12.39\end{array}$ \\
\hline
\end{tabular}




\section{Agricultural Research \& Technology: Open Access Journal}

\begin{tabular}{|c|c|c|c|c|c|c|c|c|c|c|c|c|c|c|c|}
\hline \multirow{3}{*}{$\begin{array}{l}\text { Sum- } \\
\text { mer }\end{array}$} & June & $\begin{array}{c}14.00 \pm \\
0.76\end{array}$ & $\begin{array}{c}32.73 \pm \\
1.78\end{array}$ & $\begin{array}{c}70.00 \pm \\
3.81\end{array}$ & $\begin{array}{c}116.73 \pm \\
6.36\end{array}$ & $\begin{array}{c}5.44 \pm \\
0.30\end{array}$ & 0 & $\begin{array}{l}122.17 \\
\pm 6.65\end{array}$ & $\begin{array}{c}8.65 \pm \\
0.47\end{array}$ & $\begin{array}{c}20.21 \pm \\
1.10\end{array}$ & $\begin{array}{c}43.23 \pm \\
2.35\end{array}$ & $\begin{array}{c}72.08 \pm \\
3.93\end{array}$ & $\begin{array}{c}4.63 \pm \\
0.25\end{array}$ & 0 & $\begin{array}{l}76.71 \\
\pm 4.18\end{array}$ \\
\hline & July & 0 & $\begin{array}{c}1.29 \pm \\
0.07\end{array}$ & $\begin{array}{c}43.13 \pm \\
2.35\end{array}$ & $\begin{array}{c}44.42 \pm \\
2.42\end{array}$ & $\begin{array}{l}17.34 \\
\pm 0.94\end{array}$ & 0 & $\begin{array}{c}61.76 \pm \\
3.36\end{array}$ & 0 & $\begin{array}{c}0.79 \pm \\
0.04\end{array}$ & $\begin{array}{c}28.49 \pm \\
1.55\end{array}$ & $\begin{array}{c}29.29 \pm \\
1.60\end{array}$ & $\begin{array}{l}12.40 \\
\pm 0.68\end{array}$ & 0 & $\begin{array}{r}41.69 \\
\pm 2.27\end{array}$ \\
\hline & Aug. & 0 & 0 & $\begin{array}{c}4.76 \pm \\
0.26\end{array}$ & $\begin{array}{c}4.76 \pm \\
0.26\end{array}$ & $\begin{array}{l}18.34 \\
\pm 1.00\end{array}$ & $\begin{array}{c}10.09 \pm \\
0.55\end{array}$ & $\begin{array}{c}33.20 \pm \\
1.81\end{array}$ & 0 & 0 & $\begin{array}{l}4.80 \pm \\
0.25\end{array}$ & $\begin{array}{l}4.80 \pm \\
0.25\end{array}$ & $\begin{array}{r}10.80 \\
\pm 0.59\end{array}$ & $\begin{array}{c}6.76 \pm \\
0.37\end{array}$ & $\begin{array}{r}22.36 \\
\pm 1.19\end{array}$ \\
\hline \multicolumn{2}{|c|}{ Average } & $\begin{array}{c}4.67 \pm \\
1.51\end{array}$ & $\begin{array}{c}11.34 \pm \\
3.84\end{array}$ & $\begin{array}{c}39.30 \pm \\
6.76\end{array}$ & $\begin{array}{c}55.30 \pm \\
10.21\end{array}$ & $\begin{array}{l}13.71 \\
\pm 1.54\end{array}$ & $\begin{array}{c}3.36 \pm \\
1.13\end{array}$ & $\begin{array}{c}72.38 \pm \\
8.27\end{array}$ & $\begin{array}{c}2.88 \pm \\
0.93\end{array}$ & $\begin{array}{c}7.00 \pm \\
2.37\end{array}$ & $\begin{array}{c}25.51 \pm \\
3.96\end{array}$ & $\begin{array}{c}35.39 \pm \\
6.08\end{array}$ & $\begin{array}{c}9.28 \pm \\
0.88\end{array}$ & $\begin{array}{c}2.25 \pm \\
0.74\end{array}$ & $\begin{array}{l}46.92 \\
\pm 4.98\end{array}$ \\
\hline \multicolumn{2}{|c|}{ Total } & 1353.79 & 639.65 & 357.64 & 2351.08 & 172.91 & 213.45 & 2737.44 & 382.89 & 181.24 & 110.25 & 674.35 & 54.63 & 53.52 & 782.52 \\
\hline \multicolumn{2}{|c|}{ General average } & $\begin{array}{c}56.41 \pm \\
8.34\end{array}$ & $\begin{array}{c}26.65 \pm \\
3.76\end{array}$ & $\begin{array}{c}14.90 \pm \\
2.35\end{array}$ & $\begin{array}{c}97.96 \pm \\
10.36\end{array}$ & $\begin{array}{c}7.20 \pm \\
0.73\end{array}$ & $\begin{array}{c}8.89 \pm \\
0.98\end{array}$ & $\begin{array}{l}114.06 \\
\pm 9.71\end{array}$ & $\begin{array}{c}31.91 \pm \\
4.63\end{array}$ & $\begin{array}{c}15.10 \pm \\
2.13\end{array}$ & $\begin{array}{c}9.19 \pm \\
1.45\end{array}$ & $\begin{array}{c}56.20 \pm \\
5.79\end{array}$ & $\begin{array}{c}4.55 \pm \\
0.44\end{array}$ & $\begin{array}{c}4.46 \pm \\
0.49\end{array}$ & $\begin{array}{r}65.21 \\
\pm 5.41\end{array}$ \\
\hline \multicolumn{2}{|c|}{$\%$} & 49.46 & 23.37 & 13.07 & 85.89 & 6.31 & 7.8 & 100 & 48.93 & 23.16 & 14.09 & 86.18 & 6.98 & 6.84 & 100 \\
\hline
\end{tabular}

For each stage of pest, means for population density of W. mimosae among the untreated (ant presence) and treated trees (ant exclusion) with the pesticide were compared using paired T-test.

The obtained results are presented in Tables $3 \& 4$ and graphically illustrated in Figure 2, showed that, the foraging ants were more abundant on the branches of untreated sunt trees and were absent on the branches of treated sunt trees with diazinon $60 \% \mathrm{EC}(3 \mathrm{ml} /$ Liter water) during all studied months in the both two years of study. Also, the results indicated that significantly greater differences in the numbers of different stages of $W$. mimosae were occurred between trees with ants and without ants in all dates of inspection during the both years of study. The mean number of total population per branch through the whole year was $110.18 \pm 9.39$ and $114.06 \pm 9.71$ individuals per branch in trees containing ants and $66.84 \pm 5.53$ and $65.21 \pm 5.41$ individuals per branch in trees which ants were excluded during the first and second years, respectively.

Over first year (2016/2017), the mean numbers of insect population through the whole year was $50.03 \pm 7.41,28.86 \pm 4.19$, $16.81 \pm 2.82,95.70 \pm 10.21,6.88 \pm 0.71$ and $7.60 \pm 0.81$ individuals per branch in trees with ants and it was $29.72 \pm 4.28,17.21 \pm 2.49$, $10.84 \pm 1.82,57.77 \pm 5.99,4.58 \pm 0.45,4.49 \pm 0.47$ and $66.84 \pm 5.53$ individuals per branch in trees without ants were recorded on the first instar nymphs, second instar nymphs, third instar nymphs, pre-adults total, adult females and gravid females of W. mimosae, respectively are represented in Table 3 and illustrated in Figure 2.

During the second year $(2017 / 2018)$ the mean numbers of insect population through the whole year was $56.41 \pm 8.34,26.65$ $\pm 3.76,14.90 \pm 2.35,97.96 \pm 10.36,7.20 \pm 0.73$ and $8.89 \pm 0.98$ individuals per branch in trees containing ants and it was $31.91 \pm$ $4.63,15.10 \pm 2.13,9.19 \pm 1.45,56.20 \pm 5.79,4.55 \pm 0.44$ and $4.46 \pm$ 0.49 individuals per branch in trees excluded ants were recorded on first instar nymphs, second instar nymphs, third instar nymphs, pre-adults total, adult females and gravid females of $W$. mimosae, respectively are represented in Table 4 and illustrated in Figure 2. The difference in the mean population density of $W$. mimosae among the untreated (with ants) and treated trees (without ants ) with the pesticide was highly significant differences (paried T-test) during the two years of study, the values t-test during the first year (2016/2017) were $(3.17,2.98,2.73$ and 3.94) and through the second year $(2017 / 2018)$ were $(3.18,3.25,3.05$ and 3.96$)$ for the pre-adults total, adult females, gravid females and total population of $W$. mimosae, respectively at $\mathrm{P} \leq 0.05$.

The aforementioned results clearly showed that the high abundance of $W$. mimosae on sunt trees containing foraging ants. As well as, mean numbers of different stages of $W$. mimosae population on trees included foraging ants was substantially greater about one and half times than that on trees of foraging ants exclusion. This is may be due the ants may increase the survival and reproductive capacity of the coccids [22] and can stimulate its development [23]. Ants can protect hemipteran species from their natural enemies thereby compromising biological control [24]. Also, ants may remove dead scale insects from aggregation, perhaps reducing the spread of parasitoids into the remainder [6]. Removal of honeydew improves the sanitation of coccid aggregation by reducing physical fouling caused by both the sugary excreta and the sooty moulds which grow on it [25].

Generally, it may be concluded that the honeydew-seeking ants can markedly stimulate the development of $W$. mimosae on sunt trees. These results agree with that obtained by Ahmed [26], in Egypt, however with different insect species, also studied the effect of ant exclusion on sugarcane infestation by Pulvinaria tenuivalvata (Newatead). He reported that the foraging ants were more abundant on the sugarcane plants of untreated plots and were absent on the sugarcane plants of treated plots during the period of the experiment.

\section{Evaluation of the density dependent-relationship be- tween population density of different stages of $W$. mi- mosae and ants density}

The density- dependent response was determined for the honeydew-seeking ants, Messon sp. to the different stages of $W$. mimosae population during the different seasons of year (autumn, winter, spring and summer) and on the over year through the two years of study (2016/2017 and 2017/2018) are represented in Table 5 and graphically illustrated in Figure 3 \& 4 .

By plotting numbers of the percentages of ants density on sunt trees (dependent factor) against the age structure of different stages of $W$. mimosae (independent factor), the analysis indicated 
that the percentages of ants were relatively more correlated and positive with the percentages of adult females and gravid females of pest in all seasons of the year and on the over year through the both years of study. But, there are negative correlations between the percentages of ants and the percentages of pre-adults population of $W$. mimosae during the all seasons of the year and on the whole year through the two years are represented in Table 5 and graphically illustrated in Figure 3 \& 4.

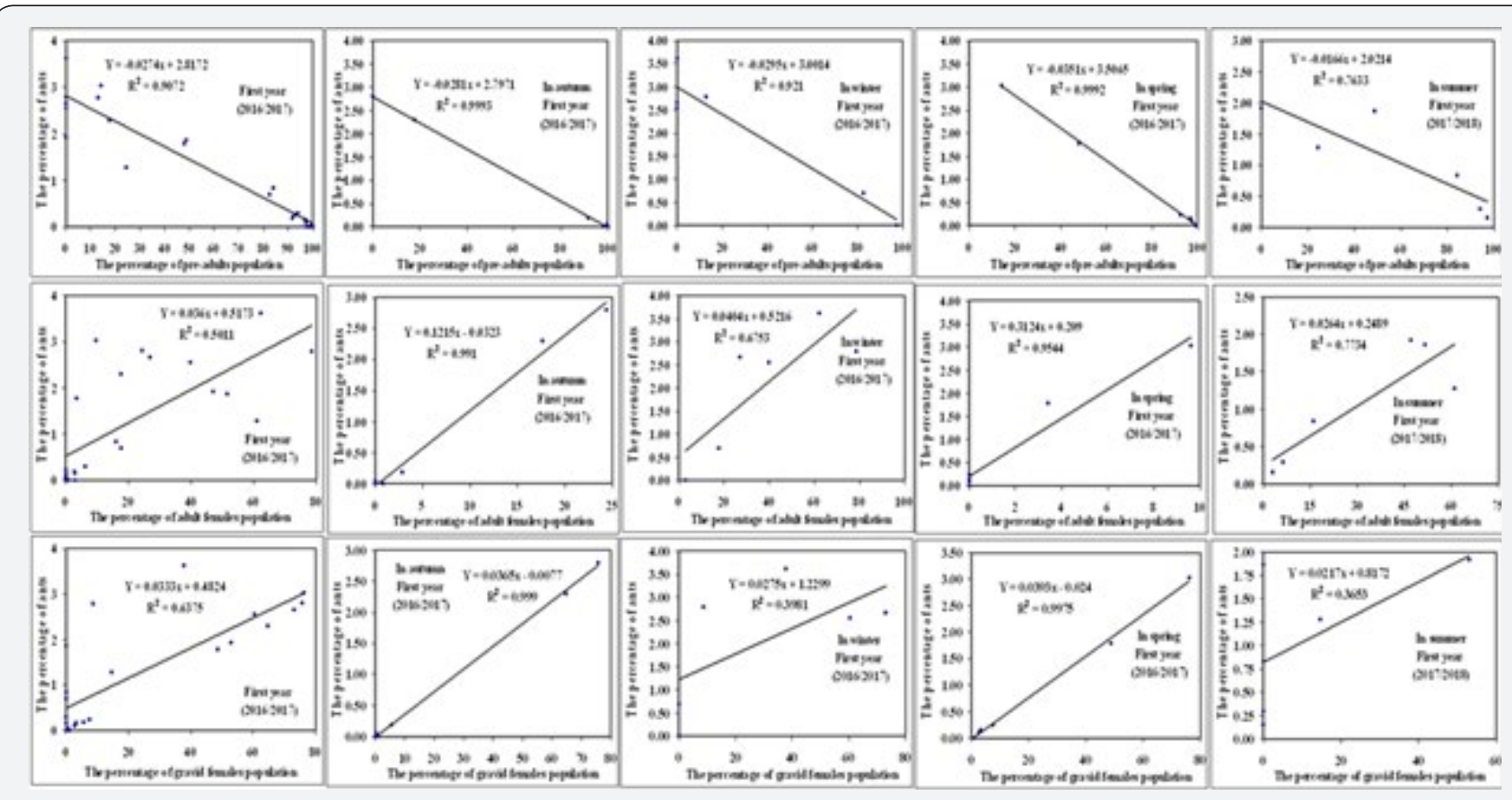

Figure 3: Relationship between the percentages of the different stages of $W$. mimosae population and the percentages of ants, Messon sp. on branches sunt trees during the first years (2016/2017).

Table 5: The seasonal simple correlation and regression values when the counts of the percentages of different stages of $W$. mimosae population were plotted versus the percentage of ant density, Messon sp. on branches of sunt trees during the two successive years (2016-2018).

\begin{tabular}{|c|c|c|c|c|c|c|c|}
\hline \multirow{2}{*}{ Season } & \multirow{2}{*}{ Analysis } & \multicolumn{3}{|c|}{$2016 / 2017$} & \multicolumn{3}{|c|}{$2017 / 2018$} \\
\hline & & Pre-adults & Adult females & Gravid Females & Pre-adults & Adult Females & Gravid Females \\
\hline \multirow{5}{*}{ Autumn } & $\mathrm{a}$ & 2.8 & -0.03 & -0.01 & 2.32 & -0.001 & -0.03 \\
\hline & r & $-0.9993^{* *}$ & $0.991^{* *}$ & $0.999 * *$ & $-0.994^{* *}$ & $0.939 *$ & $0.9998^{* *}$ \\
\hline & $\mathrm{b}$ & $-0.03^{* *}$ & $0.12^{* *}$ & $0.04^{* *}$ & $-0.02^{* *}$ & $0.09 *$ & $0.03^{* *}$ \\
\hline & S.E & 0.0004 & 0.0058 & 0.0006 & 0.0013 & 0.0159 & 0.0003 \\
\hline & $\mathrm{t}$ & $-75.53^{* *}$ & $21.00^{* *}$ & $62.69^{* *}$ & $-18.81^{* *}$ & $5.55^{*}$ & $95.26^{* *}$ \\
\hline \multirow{5}{*}{ Winter } & a & 3 & 0.52 & 1.23 & 2.37 & 0.44 & 0.74 \\
\hline & $\mathrm{r}$ & $-0.92^{* *}$ & $0.68^{*}$ & 0.4 & $-0.903^{* *}$ & 0.518 & 0.6279 \\
\hline & $\mathrm{b}$ & $-0.03^{* *}$ & $0.04^{*}$ & 0.03 & $-0.02^{* *}$ & 0.03 & 0.03 \\
\hline & S.E & 0.004 & 0.014 & 0.017 & 0.004 & 0.014 & 0.012 \\
\hline & $\mathrm{t}$ & $-6.83^{* *}$ & $2.88 *$ & 1.63 & $-6.11^{* *}$ & 2.07 & 2.6 \\
\hline \multirow{5}{*}{ Spring } & a & 3.51 & 0.21 & -0.02 & 2.89 & 0.21 & -0.05 \\
\hline & r & $-0.999 * *$ & $0.95^{* *}$ & $0.998^{* *}$ & $-0.986^{* *}$ & $0.888^{* *}$ & $0.991^{* *}$ \\
\hline & $\mathrm{b}$ & $-0.04^{* *}$ & $0.31^{* *}$ & $0.04^{* *}$ & $-0.03 * *$ & $0.25^{* *}$ & $0.03^{* *}$ \\
\hline & S.E & 0.0005 & 0.0341 & 0.001 & 0.002 & 0.044 & 0.002 \\
\hline & $\mathrm{t}$ & $-72.11^{* *}$ & $9.15^{* *}$ & $40.35^{* *}$ & $-17.02^{* *}$ & $5.64^{* *}$ & $21.22^{* *}$ \\
\hline
\end{tabular}


Agricultural Research \& Technology: Open Access Journal

\begin{tabular}{|c|c|c|c|c|c|c|c|}
\hline \multirow{5}{*}{ Summer } & a & 2.02 & 0.25 & 0.82 & 2.54 & -0.03 & 0.7 \\
\hline & $\mathrm{r}$ & $-0.76^{*}$ & $0.77^{*}$ & 0.37 & $-0.98 * *$ & $0.88^{* *}$ & 0.58 \\
\hline & $\mathrm{b}$ & $-0.02^{*}$ & $0.03^{*}$ & 0.02 & $-0.02 * *$ & $0.04^{* *}$ & 0.04 \\
\hline & S.E & 0.005 & 0.007 & 0.014 & 0.002 & 0.007 & 0.015 \\
\hline & $\mathrm{t}$ & $-3.59 *$ & $3.69 *$ & 1.52 & $-15.05^{* *}$ & $5.34^{* *}$ & 2.33 \\
\hline \multirow{5}{*}{$\begin{array}{c}\text { The whole } \\
\text { year }\end{array}$} & $\mathrm{a}$ & 2.82 & 0.52 & 0.48 & 2.46 & 0.39 & 0.37 \\
\hline & $\mathrm{r}$ & $-0.91^{* *}$ & $0.50 * *$ & $0.64^{* *}$ & $-0.96 * *$ & $0.55^{* *}$ & $0.68^{* *}$ \\
\hline & $\mathrm{b}$ & $-0.027^{* *}$ & $0.036^{* *}$ & $0.033^{* *}$ & $-0.02 * *$ & $0.03^{* *}$ & $0.03^{* *}$ \\
\hline & S.E & 0.002 & 0.008 & 0.005 & 0.001 & 0.006 & 0.005 \\
\hline & $\mathrm{t}$ & $-14.66^{* *}$ & $4.70^{* *}$ & $6.22^{* *}$ & $-22.46^{* *}$ & $5.23^{* *}$ & $6.86^{* *}$ \\
\hline
\end{tabular}

$a=$ Constant; $r=$ Simple correlation; $b=$ Simple regression; S.E = Standard error; ${ }^{*}$ Significant at $P \leq 0.05 ;{ }^{* *}$ Highly significant at $P \leq 0.01$

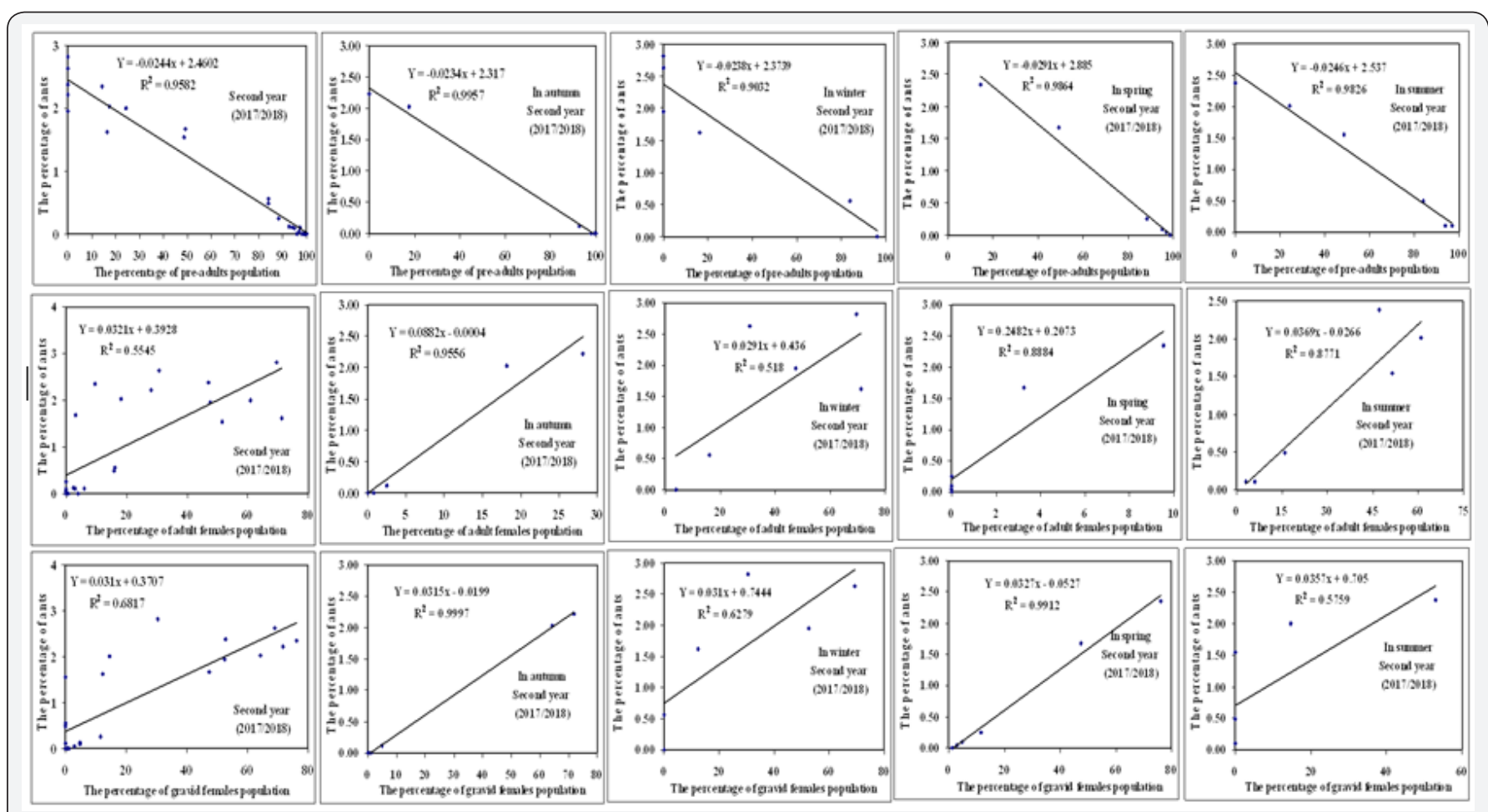

Figure 4: Relationship between the percentages of the different stages of $W$. mimosae population and the percentages of ants, Messon sp. on branches sunt trees during the second years (2017/2018).

The simple regression revealed that, significant increase in the percentages of ants, Messon sp. was shown in the different seasons of the year and on the whole year with increasing the percentages of adult females of insect ranged from ( 0.03 to $0.31 \%$ ) for the first year and from (0.03 to $0.24 \%$ ) during the second year, respectively. A similar trend in the increase of the percentages of ants and the percentages of gravid females was observed. The effect regression coefficient (b) indicates that an increase of $1 \%$ in the population of gravid females, would increase the percentages of ants about $0.02-0.04 \%$ for the first year and 0.03-0.04 \% during the second year in the different seasons of the year and on the whole year, respectively. Differently, the synchronization between percentages of pre-adults population and the percentages of ants activity are negative. An increase of one $\%$ in the population of pre-adults, would decrease the percentages of ants density about $0.02-0.04 \%$ for the first year and $0.02-0.03 \%$ during the second year in the different seasons of the year and on the whole year, respectively are represented in Table 5 and graphically illustrated in Figure $3 \& 4$.

The density relationship between the percentages of ants density on sunt trees (Y) against the percentages of different stages of $W$. mimosae population $(\mathrm{X})$ could be represented by the following submodels.

\section{In the first year $(2016 / 2017)$}

$$
\begin{aligned}
& \text { a. Pre-adults population stage: } \\
& Y=2.7971-0.0281 x \text { In autumn } ; Y=3.0014-0.0295 x \text { In winter } \\
& Y=3.5065-0.0351 x \text { In spring } ; Y=2.0214-0.0166 x \text { In summer } \\
& Y=2.8172-0.0274 x \text { Over the year }
\end{aligned}
$$




\section{b. Adult females population stage:}

$$
\begin{aligned}
& Y=-0.0323+0.1215 x \text { In autumn } Y=0.5216+0.0404 x \text { In winter } \\
& Y=0.209+0.3124 x \text { In spring } Y=0.2489+0.0264 x \text { In summer } \\
& Y=0.5173+0.036 x \text { Over the year }
\end{aligned}
$$

\section{c. Gravid females population stage:}

$$
\begin{aligned}
& Y=-0.0077+0.0365 x \text { In autumn } Y=1.2299+0.0275 x \text { In winter } \\
& Y=-0.024+0.0393 x \text { In spring } Y=0.8172+0.0217 x \text { In summer } \\
& Y=0.4824+0.0333 x \text { Over the year }
\end{aligned}
$$

\section{In the second year $(2017 / 2018)$}

\section{a. Pre-adults population stage:}

$$
\begin{aligned}
& Y=2.317-0.0234 x \text { In autumn } Y=2.3739-0.0238 x \text { In winter } \\
& Y=2.885-0.0291 x \text { In spring } ; Y=2.537-0.0246 x \text { In summer } \\
& Y=2.4602-0.0244 x \text { Over the year }
\end{aligned}
$$

\section{b. Adult females population stage:}

$$
\begin{aligned}
& Y=-0.0004+0.0882 x \text { In autumn } Y=0.436+0.0291 x \text { In winter } \\
& Y=0.2073+0.2482 x \text { In spring } ; Y=-0.0266+0.0369 x \text { In summer } \\
& Y=0.3928+0.0321 x \text { Over the year } \\
& \text { c. } \quad \text { Gravid females population stage: } \\
& Y=-0.0199+0.0315 x \text { In autumn } Y=0.7444+0.031 x \text { In winter } \\
& Y=-0.0527+0.0327 x \text { In spring } Y=0.705+0.0357 x \text { In summer } \\
& Y=0.3707+0.031 x \text { Over the year }
\end{aligned}
$$

\section{c. Gravid females population stage:}

Overall, the synchronization between the percentages of adult females and gravid females of pest and percentage of ants density were good and the simple regression analysis were more correlated and its positive in all seasons of the year and on the over year. In contrary, the percentages of pre-adults individuals and the percentages of ants were not good and it exhibited negative response in all seasons of the year and on the whole year. The obtained differentiations may be that the adult females and gravid females of pest produced more honeydew than preadults individuals. These results were coincided with results of Henneberry et al. [27], mentioned that the adult females of Bemisia tabaci produced more honeydew than nymphs and was subject to large degrees of variation. Also, changes in plant physiology may be reflected in B. tabaci feeding biology.

There is little published information comparing the quantity of honeydew produced by adult females and nymphs of insect pests. Henneberry et al. [27], reported that the honeydew drops of females, on average, were larger in size compared with those of nymphs. The implications of the differences in honeydew excreted by nymphs and females are unknown. However, differences in amounts may be partially explained by differences in the sizes of nymphs and females. The carbohydrate aspects of the pest host interaction are complex and may significantly reflect on biological and ecological adaptations of the insect. Blua \& Toscano [28], reported that nymphs did not initiate honeydew production for 3 to 5 days following emergence.

From this study, it may be concluded that the population density of honeydew-seeking ants on sunt trees is interfering with biological control, increasing the possibility of out breaks of the honeydew producing insects. Also, the method of excluding ants that is effective and non disruptive to the ecosystem in urgently required to ensure continued stability in sunt trees in Luxor Governorate, southern Egypt.

\section{References}

1. Argov Y, Podoler H, Bar-Shalom O, Rosen D (1987) Mass rearing of the Florida wax scale, Ceroplastes floridensis, for production of natural enemies. Phytoparasitica 15(4): 277-287.

2. Hodges GS, RuterJR, Braman SK (2000) Susceptibility of Ilex species, hybrids and cultivars to Florida wax scale (Ceroplastes floridensis Comstock). Journal of Environmental Horticulture 19: 32-36.

3. Ben-Dov Y, Guerrieri E (2009) Waxiella mimosae (Signoret) (Hemiptera, Coccoidea, Coccidae) and its parasitoid Anicetus africanus (Girault) (Hymenoptera, Encyrtidae) newly recorded from Israel. Bulletin de la Société entomologique de France 114(1): 83-89.

4. Parmesan C (2007) Influences of species, latitudes and methodologies on estimates of phenological response to global warming. Glob Chang Biol 13(9): 1860-1872.

5. Douglas AE (2006) Phloem-sap feeding by animals: problems and solutions. J Exp Bot 57(4): 747-754.

6. Buckley RC (1987) Ant-plant-homopteran interaction. Advances in Ecological Research 16: 53-85.

7. Samways MJ, Nel M, Prins AA (1982) Ants (Hymenoptera: Formicidae) foraging in citrus trees and attending honeydew producing Homoptera. Phytophylactica 14(4): 155-157.

8. Letson D (1973) The ant mosatic-tropical tree crops and the limiting of pests and disease. Pests Articles and News Sumarics 19(3): 311-314.

9. Rogers ME, Stansly PA (2006) Biology and management of the Asian citrus psyllid, Diaphorina citri Kuwayama, in Florida Citrus. EDIS ENY739.

10. Jones ME, Paine TD (2012) Associations between invasive eucalyptus psyllids and arthropod litter communities under tree canopies in southern California. Entomologia Experimentalis Et Applicata 143(3): 280-291.

11. Das GM (1959) Observation on the association of ants with coccids of tea. Bull Entomol Res 50(3): 437-448.

12. Mashwitz U, Dumpert K, Botz T, Rohe W (1991) A silk-nest weaving Dolichoderine ant in a Malayan rain forest. Insect Sociaux Paris 38(3): 307-316.

13. Clarke SR, De Barr GL, Berisford CW (1989) The life history of Toumeyella pini (King) (Homoptera: Coccidae) in loblolly pine seed orchard in Georgia. Can Entomol 121(10): 853-860.

14. Briese DT (1982) Damage to saltbush by the coccid, Pulvinaria maskelli Olliff, and the role played by an attendant ant. J Aust Entomol Soc 21(4): 293-294.

15. Gaigher R, Samways MJ, Henwood J, Jolliffe K (2011) Impact of a mutualism between an invasive ant and honeydew-producing insects on a functionally important tree on a tropical island. Biological Invasions 13: 1717-1721. 
16. Remier NJ, Cope M, Yasuda G (1993) Interference of Pheidole negacephala (Hymenoptera: Formicidae) with biological control of Coccus Viridis (Homoptera: Coccidae) in Coffee. Environ Entomol 22(2): 483-488.

17. Way MJ (1954) Studies on the association of the ant, Oecophylla longinoda (Latr.) (Farmicidae) with the scale insect, Saissetia Zanzibarensis williams (Coccidae). Bull Entomol Res 45(1): 113-134.

18. Carroll CR, Janzen DH (1973) Ecology of foraging ants. Ann Rev Ecol Syst $4:$ 231-257.

19. Beattie AJ (1985) The green scale, Coccus Viridis (Green) (Homoptera: Coccidae), and ants. Hawaii Entomol Soc 16: 349-355.

20. Fisher RA (1950) Statistical methods for research workers. Oliver and Boyd Ltd., Edinburgh, London. (12 ${ }^{\text {th }}$ edn). pp. 518.

21. MSTATC (1980) A Microcomputer Program of the Design Management and Analysis of Agronomic Research Experiments. Michigan State Univ, USA.

22. Way MJ (1963) Mutualism between ants and honeydew producing Homoptera. Ann Rev Entomol 8: 307-344.

23. James DG, Stevens MM, O'Malley KJ (1997) The impact of foraging ants on population of Coccus hesperidum L. (Homoptera: Coccidae) and
Aonidiella aurantii (Maskell) (Hemiptera: Diaspididae) in an Australian citrus grove. J Appl Entomol 121(1-5): 257-259.

24. Mansour R, Suma P, Mazzeo G, La Pergola A, Pappalardo V (2012) Interactions between the ant, Tapinoma nigerrimum (Hymenoptera: Formicidae) and the main natural enemies of the vine and citrus mealybugs (Hemiptera: Pseudococcidae). Biocontrol Science and Technology 22: 527-537.

25. Justum AR, Cherret JM, Fisher M (1981) Interaction between the fanua of citrus trees in Trinidad and the ants, Atta cephalotes and Azteca sp. J A ppl Ecol 18(1): 187-195.

26. Ahmed AOA (2004) Studies on the red-striped soft scale insect, Pulvinaria tenuivalvata (Newstead), infesting sugarcane in Upper Egypt. Fac Agric Assiut Univ, Egypt. pp. 142.

27. Henneberry TJ, Forlow Jech L, de la Torre T (2001) Honeydew production by sweet potato whitefly adults and nymphs. Arizona Cotton Report, University of Arizona College of Agriculture and Life Sciences, USA.

28. Blua MJ, Toscano NC (1994) Bemisia argentifolii (Homoptera: Aleyrodidae) development and honeydew production as a function of cotton nitrogen status. Environ Entomol 23(2): 316-321.

\section{Your next submission with Juniper Publishers will reach you the below assets}

- Quality Editorial service

- Swift Peer Review

- Reprints availability

- E-prints Service

- Manuscript Podcast for convenient understanding

- Global attainment for your research

- Manuscript accessibility in different formats

( Pdf, E-pub, Full Text, Audio)

- Unceasing customer service

Track the below URL for one-step submission https://juniperpublishers.com/online-submission.php 